\title{
FROM THE NILE RIVER TO THE ERIE CANAL: TRACING THE PHOTOGRAPHS OF THE ZANGAKI BROTHERS AT GEORGE EASTMAN HOUSE
}

\author{
by \\ Andrea Hackman \\ Bachelor of Fine Arts in Photography \\ Rhode Island School of Design in Providence, Rhode Island, 2000
}

\begin{abstract}
A thesis
presented to Ryerson University

and the George Eastman House International Museum of Photography and Film in partial fulfillment of the requirements for the degree of

Master of Arts

in the Program of

Photographic Preservation and Collections Management

Toronto, Ontario, Canada, 2009

(C) Andrea Hackman 2009
\end{abstract}




\section{AUTHOR'S DECLARATION}

I hereby declare that I am the sole author of this thesis.

I authorize Ryerson University and George Eastman House, International Museum of

Photography and Film, to lend this thesis to other institutions or individuals for the purpose of scholarly research.

I further authorize Ryerson University and George Eastman House, International Museum of Photography and Film, to reproduce this thesis by photocopying or by other means, in total or in part, at the request of other institutions or individuals for the purpose of scholarly research.

FROM THE NILE RIVER TO THE ERIE CANAL: TRACING THE PHOTOGRAPHS OF THE ZANGAKI BROTHERS AT GEORGE EASTMAN HOUSE 
Master of Arts, 2009

Andrea Hackman

Photographic Preservation and Collections Management

Ryerson University and George Eastman House

\begin{abstract}
The collection of photographs by the Zangaki Brothers at George Eastman House provide a case study for tracing a trajectory of nineteenth century photographic images made for a tourist market. Beginning with the photographers themselves and the clientele they served, to the albums the photographs were mounted into, the collections they were placed in and the subsequent modern critiques of the photographers, this thesis aims to understand decisions that ultimately define the context in which we now find the photographs.
\end{abstract}




\section{ACKNOWLEGEMENTS}

I would like to thank my professors at Ryerson and George Eastman House for their passion, insight and guidance in this unique field. A special thank you to my thesis advisor Marta Braun for her encouragement, humor and kindness and to my mentor Grant Romer for his inspiration.

I am grateful to Katena Lafkas Presutti, Valentina Branchini, Maya Dalinsky and Edith Currier for their translations of Greek, Italian, German, and French texts, respectively. Without their assistance I would have been at a huge disadvantage. Also thank you to Joseph Strubel and Jamie Allen of George Eastman House and Jeff Spurr of the Aga Khan Collection at Harvard for assisting me with accessing Zangaki photographs. Finally, without the editing of my mother, Margaret (they don't call me Hackman for nothing) Hackman, I would have been a grammatical mess. Many thanks for your time and patience. 


\section{DEDICATION}

This thesis is for my Yiayia, Olympia Gekas.

Hackman 5 


\section{TABLE OF CONTENTS}

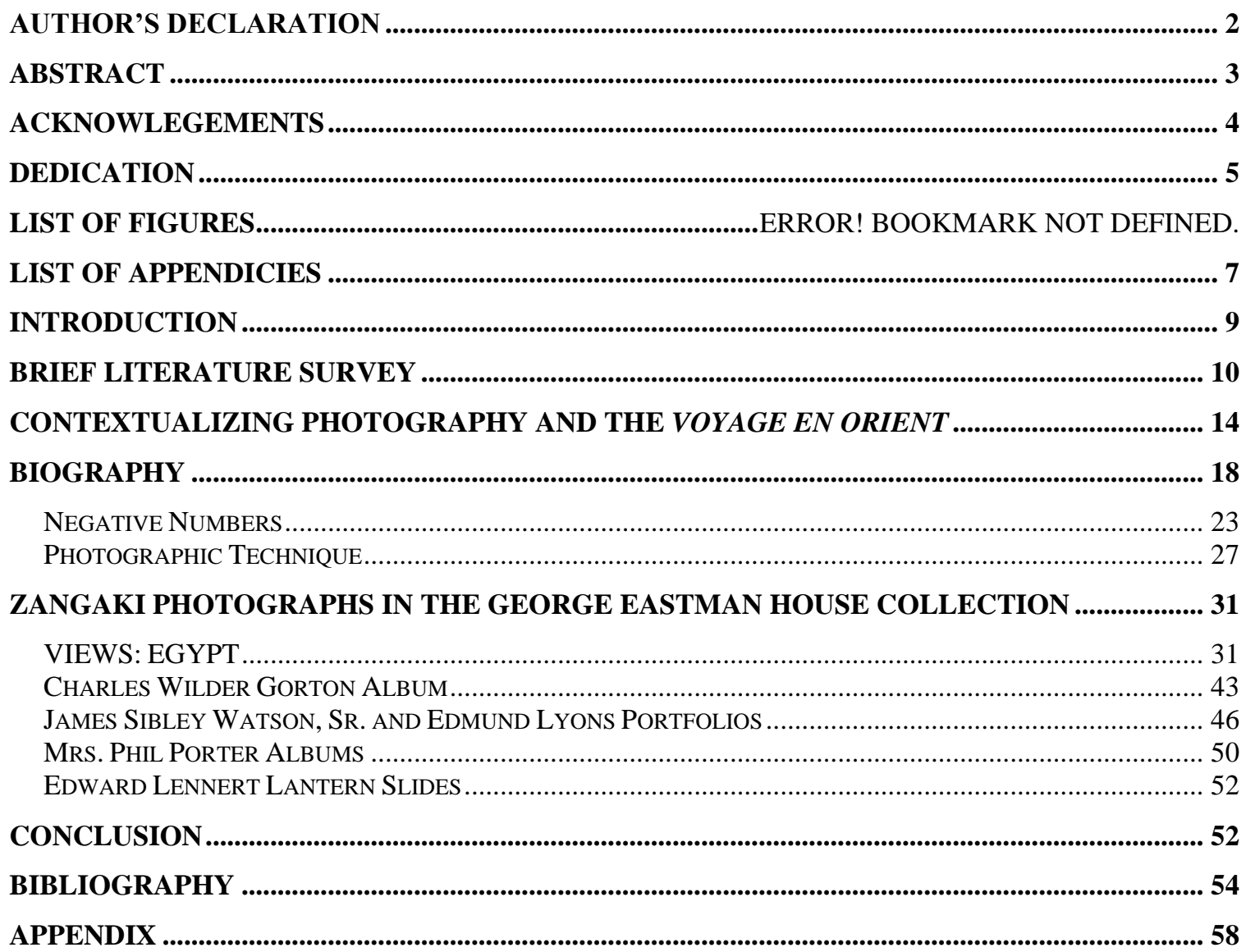




\section{LIST OF FIGURES}

FigURE 1 JoHn B. GREENE, THE BANKS OF THE NILE AT THEBES ....................................... 15

Figure 2 FÉlix Teynard, Portico of the Tomb ofAMENEMHAT, BENI HASAN .............................. 15

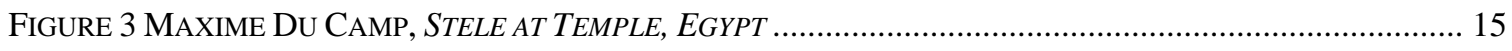

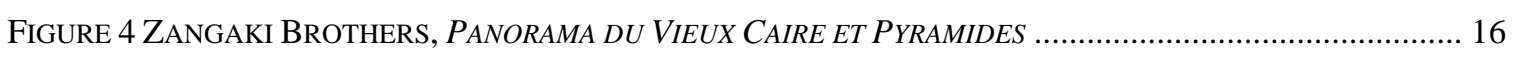

Figure 5 ZANGaki Brothers, RUE DU COMERCE A [SIC] PORT-SAID ................................................... 20

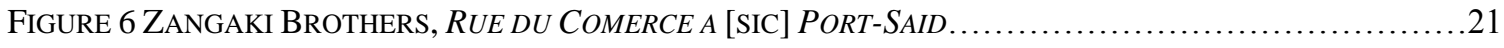

Figure 7 ZangaKI Brothers, RUE DU COMERCE A [SIC] PORT-SAID ................................................... 21

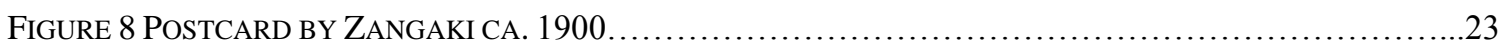

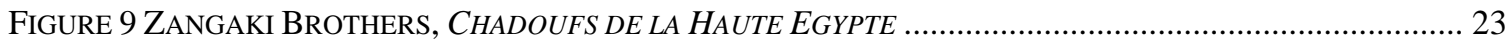

FIGURE 10 ZANGAKI BRothERS, THEBES COLOSSES DE MEMNON........................................................... 24

FigURE 11 ZANGAKI NEGATIVE Number MAP @ANDREA HACKMAN.................................................... 25

FIGURE 12 ZANGAKI BRotHERS, GRAND BAZAR AU KASR EL NIL CAIRE ................................................... 28

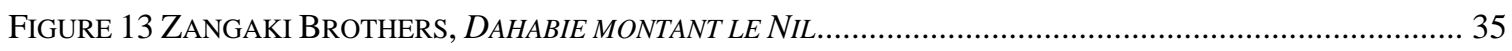

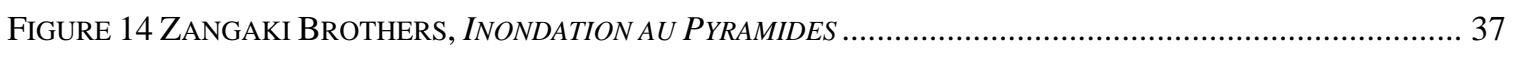

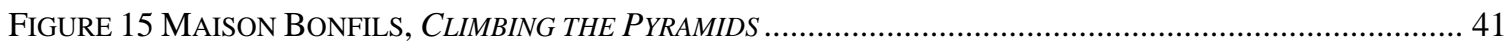

Figure 16 ZANGAKI BRothers, (JERUSALEM) INTERIEUR DE LA SAINTE-CROIX ........................45

FiguRE 17 ZANGAKI BRothers, (BETHLEEM) INTERIEUR DE LA GROTTE DE LA NATIVITIE....................45

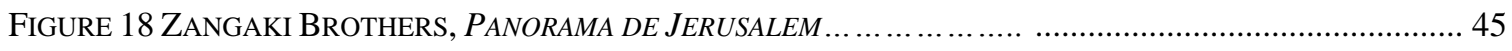

FIGURE 19 A SELECTION OF ZANGAKI PHOTOGRAPHS FROM TWO DIFFERENT PORTFOLIOS AT GEH ............. 48

FIGURE 20 ZANGAKI BROTHERS, ILE. DE ROCHER KONOSSO ............................................49

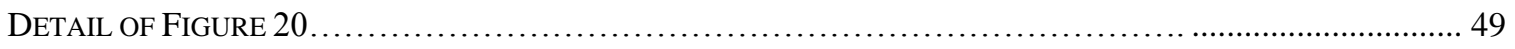

FIGURE 21 ZANGAKI BROTHERS, ABYDOS TABLEAU DES 76 RoIS D' EGYPTE ................................................. 51 


\section{LIST OF APPENDICIES}

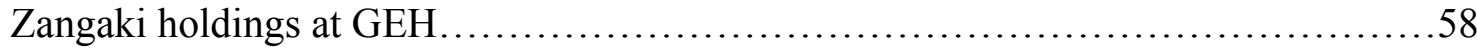

Zangaki holdings at New York Public Library, Harvard Fine Arts Library, Palestinian

Exploration Fund, George Eastman House and several publications..................61 


\section{Introduction}

This thesis focuses on 103 commercially produced tourist photographs made by Konstantinos and Georgios Zangaki, now housed in the photography collection at GEH. My aim herein is to answer biographical, historical and collections management-related questions regarding these photographs. These queries include identifying who the Zangaki brothers were, reviewing what is already known about them and establishing new insights concerning their biography, photographic career and photographic techniques. I answer what can be inferred by compiling a list of their negative numbers. My research looks into who bought Zangaki photographs, where they bought them and why. Next I trace their provenance and show how these albums and loose prints found their way into George Eastman House. I establish how these photographs were organized and stored at George Eastman House and the implications of these collectionsmanagement decisions. I consider who looks at Zangaki photographs today and why. Finally, the culmination of my research points to the question of why their work has been largely overlooked.

It is my aim to explore these questions in order to have a more comprehensive understanding of the photographs of the Zangaki Brothers in the collection at George Eastman House.

I would like to clarify the spelling, dates, terms and abbreviations in this text. When possible I copied the Zangaki titles directly from the prints, which are in French and often misspelled. If the title was illegible, I used a descriptive title in its place.

The date I assigned all the loose Zangaki photographs is ca. 1880. I determined this date after consulting with Jamie Allen, Associate Curator of Photographs at George 
Eastman House. Allen advised that according to the cataloging standards at George Eastman House, the circa clause added in front of a date may include a range of ten years before and after the specified date. Therefore ca. 1880 includes 1870-1890, covering the dates established for the height of the Zangaki studios.

The term Levant used in this thesis has traditionally been used to describe the lands east of Venice, in this thesis I defer to the American Heritage Dictionary, which defines the Levant as countries bordering on the Eastern Mediterranean. ${ }^{1}$

The abbreviation TMS is for The Museum System ${ }^{\mathrm{TM}}$, the collection management software used by George Eastman House. PPCM denotes Photographic Preservation and Collection Management, the Master's degree for which this thesis is in fulfillment of, and finally GEH is often used in place of George Eastman House International Museum of Photography and Film in Rochester, New York.

\section{Brief Literature Survey}

Researchers have found limited primary sources with which to write about the Zangaki brothers. The result is that authors on the subject of nineteenth century Near Eastern photography tend to include inaccurate, little or no biographical information on the brothers. There is, however, a plethora of publications on Near East photography in general, as well as a sampling of period guidebooks. In the following brief literature review I aim to contextualize a mere fraction of the myriad published works on Near East photography from the nineteenth century, and to name those who diminish and those who champion the Zangaki brothers in order to have a better understanding of their contemporary status.

1 William Morris, ed., American Heritage Dictionary of the English Language (New York: Houghton Mifflin Company, 1973), s.v. 'Levant'. 
Nissan Perez's 1988 Focus East is the paradigm of this genre. It is one of the more thorough and better-written accounts of nineteenth century photography in the Near East. Perez writes eloquently and definitively about the influence of Orientalism, aesthetics, religion and national identity on Near East photography. His writing on the Zangaki brothers, however, presents a bias against them. In his text, Perez negatively critiques their portraiture and uses a Zangaki photograph to illustrate his notion of a falsified, Western fantasy of the Orient actualized by photography. Although the Zangaki biography is longer than that to be found in any book until Ken Jacobson's 2007 Arabesques and Odalisques, In Focus East, Perez delivers a crushing blow to the Zangaki reputation. "Their work does not go beyond average commercial photography meant for the tourist and the occasional visitor. It is difficult to find innovative vision or groundbreaking achievement in the mass of images they must have produced." 2

It is clear Perez made an obligatory entry for them based on the sheer quantity of their images; they would have been hard to ignore for a writer on this topic. Perez, however, neglects to provide evidence for his critique, it remains an unsupported generalization. The consequence of Perez's consideration is that the Zangakis are relegated as copycat profiteers in a land of innovation and skill. This stigma has stayed with the brothers since the Perez biography is quoted and paraphrased over and over in subsequent publications; even George Eastman House cites Perez in their TMS database constituent description of the brothers.

Ken Jacobson's Odalisques \& Arabesques: Orientalist Photography 1839- 1925 is in the similar vein as Focus East, though it takes a softer, post-post modern angle on 
the roots and influences of Orientalism. The value in this work lies in the perspective Jacobson gives to understanding the Westerners awe and reverence for the Orient as well as the social context he provides for the Zangaki brothers in his chapter, "A Boom in Tourist Photography”.

The primary champion of the Zangaki cause is Greek photography historian Alkis Xanthakis. He published two articles in Greek magazines ${ }^{3}$ and has one recent unpublished piece ${ }^{4}$ solely on the brothers. His research has given me insight into nuances, such as how to spell their names correctly and where they were born. He also hails them as creative, original and skilled: Descriptions that have always passed up the brothers for more established photographers of the genre like the Maison Bonfils. The only trouble with Xanthakis is that I am not sure about his primary sources He does not cite them and in a conversation with author Ken Jacobson, he warned me to be cautious about Zangaki biographical information from Xanthakis. Ironically, Jacobson cites Xanthakis for most of his Zangaki biography in Odalisques \& Arabesques. ${ }^{5}$

Italian photography historian Italo Zannier also sings the praises of the Zangaki brothers. In his 1999 L' Egitto del grand tour nella fotografia degli Zangaki, ${ }^{6}$ Zannier gives a positive opinion of the brothers. He writes at length on the friendly collaboration between them and Hippolyte Arnoux and how they, unlike other photographers including those in Italy, photographed the local populations with dignity and respect. Zannier emphasizes that their subjects demonstrate pride and that the Zangaki brothers would

3 Alkis Xanthakis, “Zangaki Brothers,” Fotografos, September 2005 and “Zangaki Brothers,” Optikon, December 1995.

4 Alkis Xanthakis, "Photographers, Greek and others, who photographed in Greece during the 19th and 20th-centuries" (unpublished working paper, translator unknown, courtesy Hellenic Historical Archive, Athens, 2008).

5 Ken Jacobson, Odalisques \& Arabesques: Orientalist Photography 1839- 1925 (London: Quaritch, 2007).

6 Italo Zannier, L' Egitto del grand tour nella fotografia degli Zangaki (Milano: CRAF, 1999). 
often include themselves not only for fun, but to show tourists that the native population was not to be feared. Zannier commends the Zangaki's compositions above their contemporaries and makes a point to reject scholar Mounira Khemir's statement that, "...their body of work suffers from a purely commercial objective." ${ }^{, 7}$ Zannier responds that, “These photographers' objective, including Beato [Antonio Beato, a photographer based in Luxor], was obviously commercial...yet [the Zangaki brothers] remained artistically attuned throughout their career".

The nineteenth century guidebooks by Baedeker and Murray ${ }^{8}$ provide a vehicle through which we today can see the travel choices put before the Victorian tourist. In reading their itinerary suggestions and detailed descriptions of Near Eastern towns, including places to buy photographs, I was able to gain a certain level of understanding of the perspective and desires of these travelers. I have yet to find a specific reference to the Zangaki brothers in any of these guidebooks.

7 Cfr. M. Khemir, in L'Orientisme, Paris, 1994, 10.

8 K. Baedeker, ed., Palestine and Syria: Handbook for Travellers (Leipsig, K. Baedeker, 1876, 1894); K. Baedeker, ed., Egypt: Handbook for Travelers (Leipsig, K. Baedeker; London, Dulau and Co., 1878-92); John Murray, A Handbook for Travellers in Egypt. 4th ed., rev. on the spot (London: J. Murray, 1873). 


\section{Contextualizing photography and the voyage en Orient}

To photograph is to appropriate the thing photographed. It means putting oneself into a certain relation to the world that feels like knowledge-and, therefore, like power...Today everything exists to end in a photograph." - Susan Sontag ${ }^{9}$

By the mid nineteenth century, a trip to the East, also known as a voyage en Orient, was a common and fashionable Western bourgeois rite of passage. The aims of the tour were to educate, to heighten family status by "doing” all possible countries, to reconnect the true Christian with the Holy Land, and to satisfy the increased Victorian thirst for all things Oriental.

"For romantic Orientalists emotion was an end in itself, and the stimuli to awaken it could no longer be found in the West; thence the painful desire to reach the Levant."10 The morally and socially restrained nineteenth century Westerner was naturally fascinated with what was considered his hedonistic antithesis: the Orient. This Near East "leg" of a Grand Tour through Europe was facilitated by the 1869 completion of the Suez Canal, organized tours provided by Thomas Cook and the detailed suggestions of where to sleep, eat and buy souvenirs in the Murray and Baedeker guidebooks. The opening of the Suez Canal also provided more affordable access to the region, therefore the tourists were now not only aristocratic but upper middle class.

The heightened frenzy of Western leisure tours to the region was preceded by and then simultaneous with increased French and British colonial activity in the region. A general cultural fascination with the Orient, archeological explorations and political

9 Susan Sontag, On Photography (New York: Farrar, Straus and Giroux, 1977), 4 and 24.

10 Nissan Perez, Focus East, 64. 
power struggles for the region grew throughout the nineteenth century. This buildup of interest in the Levant and Egypt coincided with the invention and evolution of photography. The new medium would be employed to satisfy the colonizing desires.

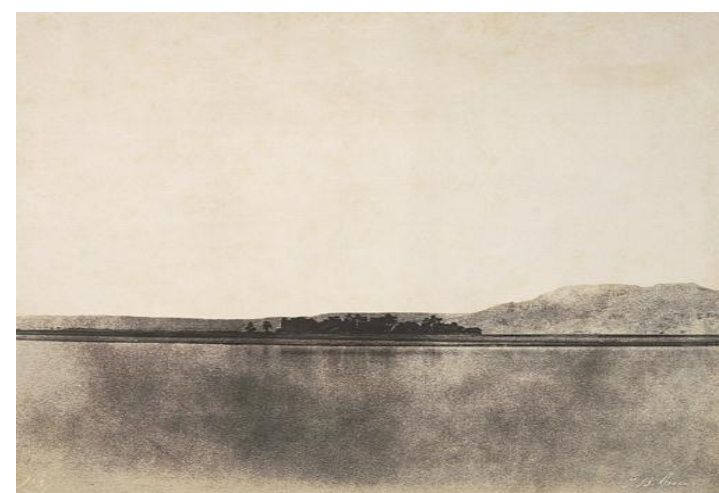

(Figure 1) John B. Greene, The Banks of the Nile at Thebes, 1854, paper print, George Eastman House, (1992:0384:0001).

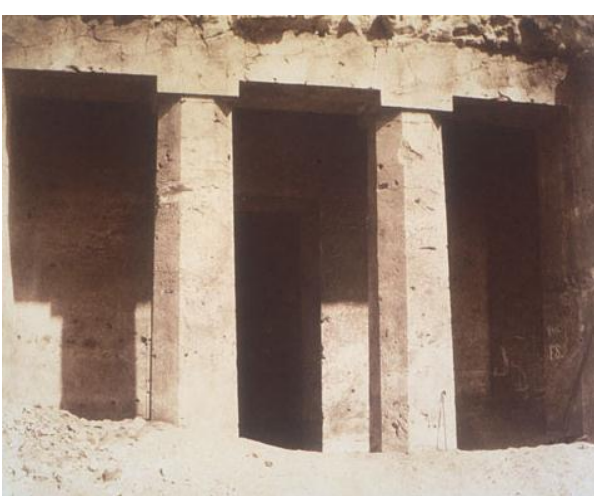

(Figure 2) Félix Teynard, Portico of the Tomb of salted Amenemhat, Beni Hasan, 1851-52, salted paper print, Metropolitan Museum of Art, (1976.607.13).

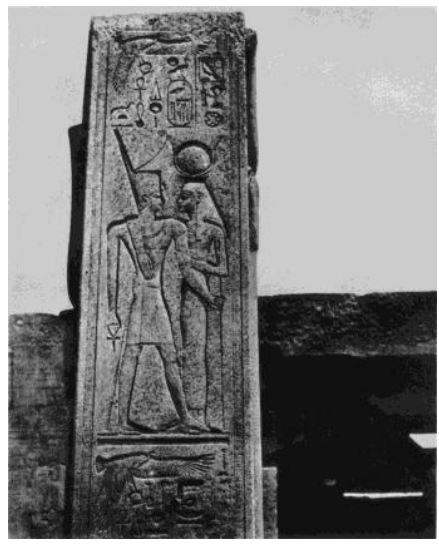

(Figure 3) Maxime Du Camp, Stele at Temple, Egypt, ca. 1850, salted paper print, Time-Life International, Die Photographie, Große Photographen, 1973, Page 38.

The 1845 hazy-dreamscape salted paper prints by John B. Greene conjure and fulfill the Western fantasy of the elusive Near East landscape (fig. 1). Architectural documents made in the form of daguerreotypes and salted paper prints had enhanced the French archeological surveys of Egypt (figs. 2 and 3) since the birth of photography. At the turn of the century, Britain conducted political mapping under the guise of the Palestinian Exploration Fund (PEF), making and collecting albumen photographs of the 
region, including ones made by the Zangakis. The notable Lieutenant Colonel Thomas Edward Lawrence (Lawrence of Arabia) was paid by the PEF to survey the strategically important Negev Desert. ${ }^{11}$ Panoramic photographs of the region like those taken by the Zangakis (fig. 4) would have aided in creating Lawrence's map of the area that secured the British defeat of the Ottomans.

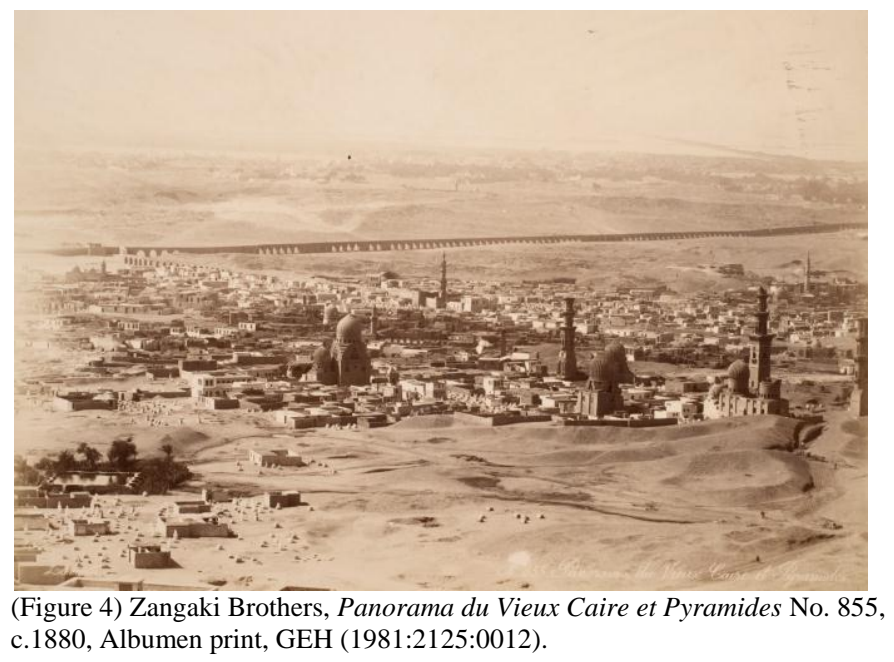

But the proliferation of nineteenth century Near East photography is a direct response to the tourist- driven market. In traveling we collect. There is an absolute desire, when an experience is out of the ordinary, to somehow contain and conquer it and bring it home. We need to exhibit to our relations and friends the landscape, painting, castle or pyramid that moved us from the everyday into a more extraordinary moment. In 1833, William Henry Fox Talbot expressed his desire to capture the view of Lake Como in front of him as a permanent and exact image; ${ }^{12}$ two years later he invented his photogenic drawing process that would do just that. ${ }^{13}$

11 C. Leonard Woolley and T. E. Lawrence, Wilderness of Zin (London: Palestine Exploration Fund, 1915). 12 William Henry Fox Talbot, The Pencil of Nature (London: Longman Brown, Green \& Longmans, 1844-46). 13 Newhall, The History of Photography (New York: Museum of Modern Art, 1982), 20. 
It is photography that so succinctly answers our desire to bring home a piece of the novel experience. "Eventually the souvenir to carry home had to be the photograph, and tourists bought commercially available views as mementos. ${ }^{" 14}$ Commercial tourist photography also marks a shift in the class of traveler that was just at this time starting to visit the Holy Land. Aristocratic travelers once used their drawing skills to make their souvenirs of foreign lands; now the upper-middle class could forgo drawing and the skills associated with it and amass photographs of their journey.

Francis Frith is credited with being the first commercially motivated photographer in Egypt and the Holy Lands. However his production facilities, opened in England in $1860,{ }^{15}$ catered to "armchair tourists," British customers who did not leave home. "There is no substitute for actual travel; but it is my ambition to provide for those to whom circumstances forbid that luxury, faithful representations of the scenes I have witnessed. $" 16$

The first local commercial studios of note and longevity in the East are credited to Hippolyte Arnoux in Cairo (1860), Antonio Beato in Luxor (1864), and Felix Bonfils in Beirut (1867). ${ }^{17}$ These big-city studios produced volumes of architectural and landscape views to serve tourists on their voyage en Orient. When the real boom of tourist photography, driven by the influx of tourists utilizing the canal, hit the Near East from 1870-1899, they were well established and stocked with thousands of $8 \times 10$ " albumen prints for sale. "Though the commercial centre for the sale of [Near] Eastern photographs remained in Egypt, distribution appears to have shifted away from the main cities towards

14 Deborah Bull, Up the Nile: A photographic excursion, Egypt 1839-1898 (New York: C. N. Potter, 1979), xvii. 15 Beaumont Newhall, The History of Photography, 105. 16 Francis Frith, Egypt and Palestine photographed and described (London: James S. Virtue, 1858-1860), introduction. 17 Jacobson, Odalisques \& Arabesques, 34. 
the heart of the tourist trail itself."18 It was at this point that the Zangaki brothers established their studio in Port Said, Egypt.

\section{Biography}

"The grand object of all traveling is to see the shores of the Mediterranean. On these shores were the four great empires of the world - the Assyrian-the Persian-the Grecian-and the Roman. All our Religion-almost all our law-almost all our Artsalmost all that sets us above savages, has come to us from the Shores of the Mediterranean. "19

The Greek island of Milos appears as an upright horseshoe in the Aegean Sea. It lies southeast of the mainland of Greece and is a volcanic member of the Cyclades island group. ${ }^{20}$ Its location provides an ideal launching point from which to navigate the Mediterranean Sea. The ports of Italy, Turkey and North Africa are all within less than a week's sail from the island. Being volcanic, Milos contains quantities of obsidian, which was useful to early civilizations. This natural glass can be traced for thousands of miles from the island. ${ }^{21}$ The ideal position of Milos and its possession of obsidian made it an important center of early Aegean civilization. The famed Venus de Milo is from Milos,

\footnotetext{
18 Perez, Focus East, 53.

19 Dr. Samuel Johnson, cited in George Wilson Bridges, Selections from Seventeen Hundred Genuine Photographs (Cheltenham: Mary Hadley, c. 1852).

20 The World Book Encyclopedia, Volume 3, (Field Enterprises Educational Corporation, 1960), s.v. "Cyclades.”

21 Colin Renfrew and Malcolm Wagstaff, eds., An Island polity: the archaeology of exploitation in Melos (Cambridge: Cambridge University Press, 1982).
} 
and Konstantinos Zangaki likened his tall and beautiful wife, Eleni, to this statue of the Goddess Aphrodite. $^{22}$

Around the year 1870, two brothers from Milos, Georgios and Konstantinos Zangaki, set off in these sparkling turquoise waters southward toward Egypt. ${ }^{23}$ A year earlier, in 1869, the Suez Canal had finally been completed. This new waterway between the Mediterranean and the Red Sea not only facilitated trading between the Middle East and Europe but it also provided easier access to the Holy Land and Egypt for well-heeled tourists. In Up the Nile, Deborah Bull writes, “The Suez Canal was a magnet that attracted people to the area." 24

Just as word of a localized boom in jobs spreads today, the brothers heeded the call to prosperity at the new port town servicing the Suez Canal. This city was called Port Said, named after the Viceroy of Egypt, Said Pasha, who gave the French permission to begin canal construction in the $1850 \mathrm{~s}^{25}$ The newly bustling city of Port Said is where the Zangakis landed, roughly 600 miles or $965 \mathrm{~km}$ south of Milos. The awe that this busy port town was built practically overnight is recorded in John Murray's 1873 A Handbook for Travellers in Egypt, "The Suez Canal, from being a 'chimerical' project has become an accomplished fact; and the town of Port Said...has sprung into existence with it."${ }^{26}$

22 Xanthakis, “Zangaki Brothers,” Fotografos, September 2005, 62.

23 Xanthakis, “Zangaki Brothers,” Optikon, December 1995, 44.

24 Bull, Up the Nile, xvii.

25 Pierre Larousse, Grand dictionnaire universel du XIXe siècle, XIV, Paris, 1866-1879, s.v. "Biography of Mohammed Said."

26 John Murray, A Handbook for Travellers in Egypt (London: J. Murray, 1873), v-vi. 


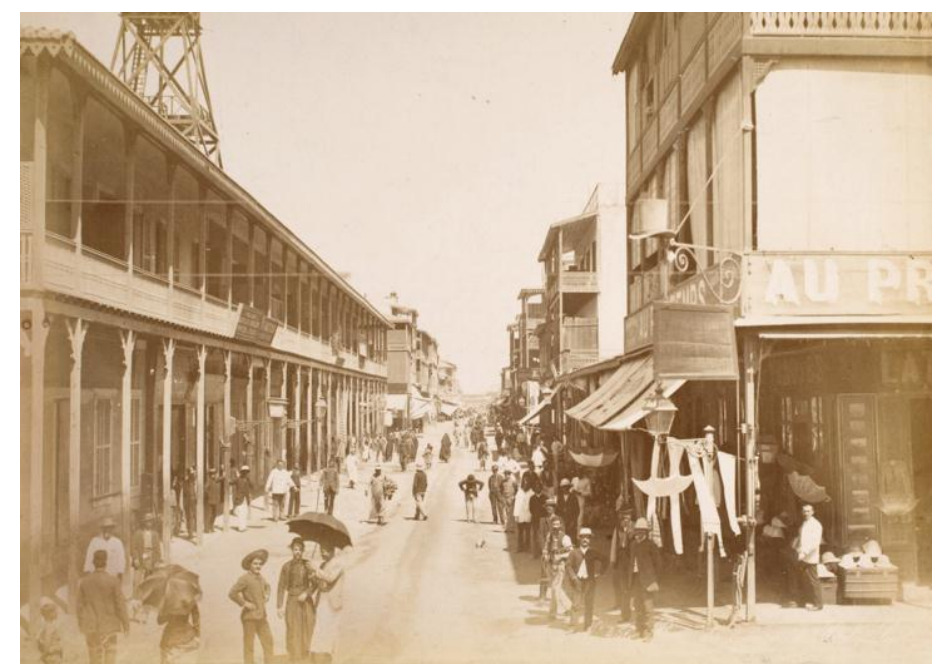

(Figure 5) Zangaki Brothers, Rue du comerce a [sic] Port-Said No. 456, c. 1880, albumen print, GEH (1986:0310:0005)

Merchants immediately set up shop to accommodate and profit from the influx of tourists. When examined under a loupe, Port Said's Rue du Commerce, pictured in the Zangaki photograph above, reveals tobacco shops, hostels, umbrellas and pith helmets for sale, like knickknacks at Disney Land. There are also photographs for sale, visible in the shop windows at the bottom right. There was clearly a niche market for photographs of Egypt and the Holy Land in Port Said. It would be the perfect point on a voyage to buy fragile photographs: right at the end while waiting for your steamer to sail back to Europe. Whether or not these are Zangaki photographs visible in the shop, I cannot be certain; however, I believe the two men in the foreground posing and looking directly at the camera (one with a jaunty stance and sombrero style hat), are the brothers (figure 6). Another view of the same street features the same man wearing a fez style hat (figure 7). 


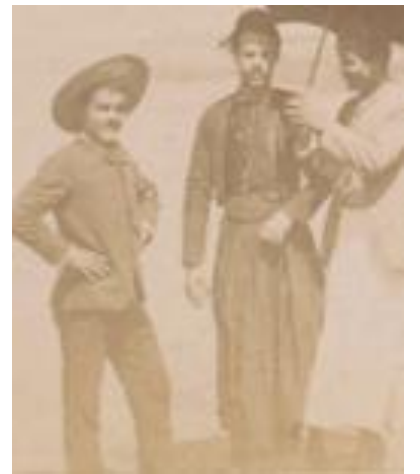

(Figure 6) Zangaki Brothers, Rue du comerce a [sic] Port-Said No. 456,

c. 1880 , albumen print, GEH (1986:0310:0005)

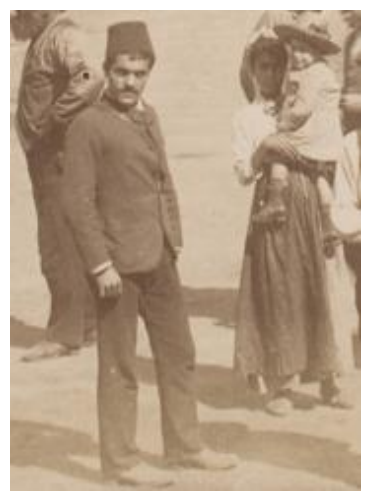

(Figure 7) Zangaki brothers, Rue $d u$ comerce a [sic] Port-Said No. 458, c. 1880 , albumen print, GEH (2001:1522:0007)

I have yet to find evidence regarding whether they had previous photographic training, but they did open their Port Said studio, "Anatolikon Photographeion," (Eastern Photo studio) shortly after arriving. ${ }^{27}$ Arnoux and Beato had moved to Port Said soon after the canal was built ${ }^{28}$ and may have acted as mentors and teachers to the Zangaki brothers. Photography historian Italo Zannier suggests that the brothers not only learned from but also initially collaborated with Arnoux. ${ }^{29}$

According to Murray's "Handbook," tourists on the beaten path would only stop over at Port Said while transferring from the steamship to a canal boat and to meet up with the Cook's tour guides. "To the general visitor Port Said offers few objects of interest in its present state, and a walk of two or three hours on shore during the stay of the steamer will more than satisfy the curiosity of most people. ${ }^{, 30}$ What better way to spend their time than to buy photographs and other mementos during their brief time at an otherwise unremarkable port town.

\footnotetext{
27 Alkis Xanthakis, "Photographers, Greek and others, who photographed in Greece." 28 Perez, Focus East, 53.

29 Zannier, L' Egitto del grand tour, 6 .

30 Murray, A Handbook for Travellers in Egypt, 244-245.
} 
Beginning in the early 1870 s, in order to supply the ever-increasing traffic of arriving and departing tourist-filled steamers with original views of the Holy Land and Egypt, the Zangaki brothers embarked on a photographic mission up the Nile. They made panoramic views of cities including Cairo, Alexandria and Jerusalem as well as country landscapes of significant biblical locations. The brothers also made balanced and detailed architectural studies of mosques, churches and ancient Egyptian monuments. Their portraits are significantly fewer in number than the landscapes and architecture studies. They include studies of interesting characters such as sheiks and snake charmers but mostly represent dignified portraits of the native populace including merchants, teachers and brides. In their most prolific time period, between 1870 and 1890, the Zangaki Brothers made the photographs we now see in so many albums and collections, including those found at George Eastman House.

The Zangaki Brothers remained career photographers throughout their lifetimes. There is no documentation to suggest that they pursued other trades as was common for merchants, including photographers, of this era. Their passion and commitment to the medium shows in the well-composed images they made. According to Alkis Xanthakis, the brothers were awarded prizes for their photographs at the 1891 International Exhibition in Palermo and the 1893 Exhibition in Paris. ${ }^{31}$ Toward the end of the $1890 \mathrm{~s}$ they opened a second studio in Cairo. Shortly afterwards Georgios died and the Port Said studio was closed. Arnoux and P. Peridis acquired an unknown quantity of the Zangaki's negatives and the rest of the studio contents were scattered. In the early twentieth century, Konstantinos became involved in publishing postcards of some of their most popular

31 Xanthakis, "Photographers, Greek and others who photographed in Greece." 
views. Figure 8 shows one of these postcards, half of which includes a reproduction of one of their scenes that can be viewed in a print (figure 9) in the George Eastman House collection.
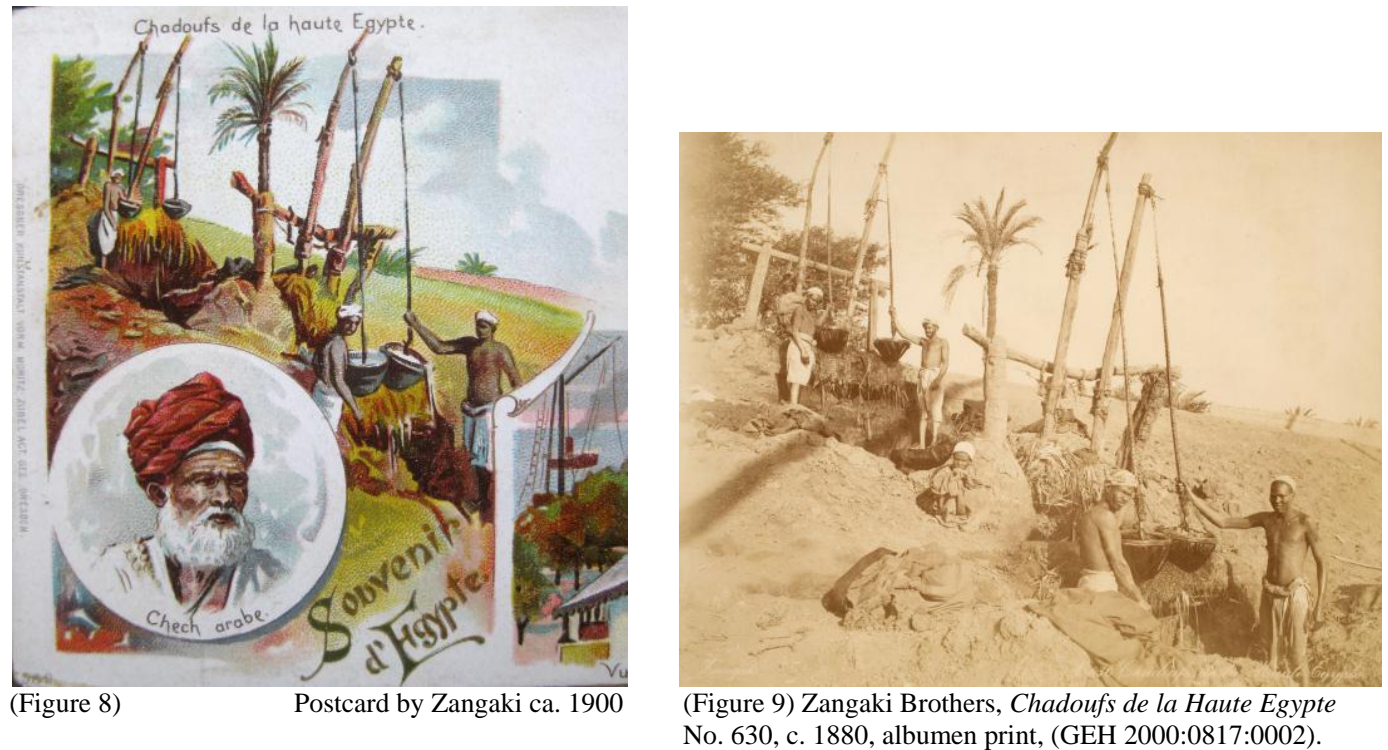

According to Xanthakis, Konstantinos died in 1913, the Cairo photo studio was subsequently closed and their remaining archive was destroyed. ${ }^{32}$ They left behind a legacy of hundreds of fine views that ultimately represent a dedication to the medium and reflect the tastes of nineteenth century western tourists in the Near East.

\section{Negative Numbers}

It is possible to trace the geographical routes the brothers took over their career by following the numbers they painted in script onto their negatives. Assigning dates to their journeys would at this time be speculative, as I have not yet been able to tell significant differences that would show the passing of time in landscapes or architecture found in different views of the same scene.

32 Xanthakis, "Photographers, Greek and others, who photographed in Greece." 
The negative numbers were printed through along with the image on the negative onto the photographic paper. Unless the image is severely faded, the numbers can be clearly read adjacent to the neatly scripted French title along the bottom of their negatives (figure 10).

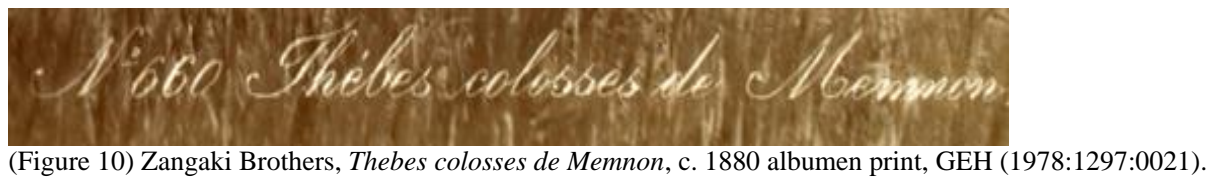

(The French language was used since, as mentioned earlier, the Government of France established Port Said in order to build the Suez Canal.) The Zangaki signature is most often found on the bottom left of the image, the number and subject title on the right. Other photographers of this era also wrote their name, title and numbered their negatives not only to claim the image as their own, but also to make clear to the fact-savoring tourist which subject and view they were buying.

When regarded in sequential order, the negative numbers correspond to a particular region, although there are some anomalies. I compiled a list of 334 Zangaki photographs with clearly visible negative numbers from the collections of the Harvard Fine Arts Library, New York Public Library, Library of Congress, George Eastman House and several published books. After organizing the list in ascending negative number order, a pattern, though not without a few anomalies, emerged. 


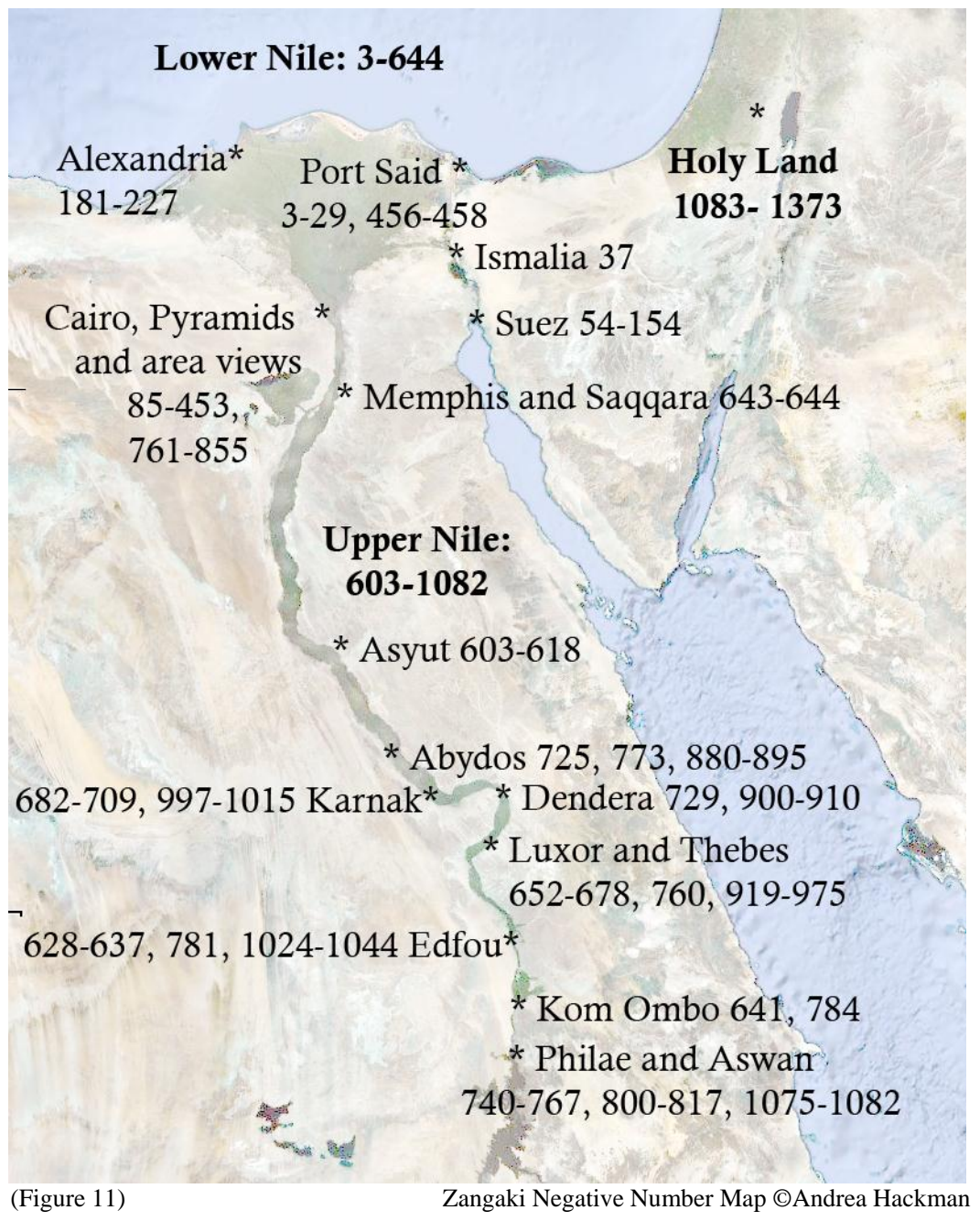

Following their Photographic Excursions

I. Lower Nile: Port Said, Cairo and vicinity, negatives 3-458

II. Middle Nile: Asyut, 603-618

III. Upper Nile: Edfou, and farther up to Kom Ombo, 619-641

IV. Down the Nile: Memphis and Saqqara, 643-644

V. Up Nile again to the ancient cities, 645-817

VI. Back down the Nile to Cairo and vicinity, 818-855

VII. Final trip up the Nile returning to the ancient cities, 856-1082

VIII. Holy Land: Jerusalem, Bethlehem and vicinity, 1083-1373 
There are three distinct regions to which the numbers correspond. The Lower Nile comprises numbers 3-644, Upper Nile includes numbers 603-1082 and the Holy Land finishes their series off with numbers 1083-1373. There is some overlap in the Lower and Upper Nile numbers. According to the numbers, the brothers photographed around their base of Port Said and made views of Ismalia, Suez, Alexandria and Cairo up to number 458. They next made three journeys up the Nile. This can be ascertained by noting that they went all the way south to the temples at Edfou and Kom Ombo for negative numbers 603-641, then returned north to Memphis, Saqqara and Cairo shooting to negative number 644. Perhaps this journey back to Cairo was to stock up on photographic supplies. For numbers 652-817 they sailed south again and photograph at Luxor, Thebes, Karnak, Abydos, Denderah and to Philae and Aswan, the furthest point up the Nile they ever went. The brothers next made another journey to Cairo and the pyramids producing numbers from the mid-700s to the mid-800s before returning for their third and final round through the upper Nile monuments: the final negative number I recorded, 1082, was from Philae. The brothers finally journeyed to the Holy Land. Fine views documenting Jerusalem, Bethlehem, Jaffa and their environs make up negative numbers 1083-1373.

Though I cannot draw a definite conclusion from the negatives alone, it is safe to say the brothers first traveled up the Nile and later into the Holy Land to make their photographs. In order to make their photographic excursions up the Nile, I believe they traveled in a Dahabie, or a Nile River cruise boat, which can be observed in several of their views along the Nile. (See a detailed description of these photographs in the Views: 
Egypt section below). I further speculate that they maintained a darkroom on this boat, allowing them to develop negatives as they went along their Nile excursions.

\section{Photographic Technique}

The Zangaki brothers created hundreds of aesthetically original and technically sound $8 " \times 10 "(21 \times 27 \mathrm{~cm})$ glass-plate negatives. In order to produce negatives of this size they employed a large format, 8 "x 10 " view camera. This was a common camera for the period; landscape photographers around the world would have used similar models made available from photography equipment purveyors in industrial cities. This camera requires a sturdy tripod and merely setting up the composition would be a physically arduous task involving the movement and adjustment of cumbersome equipment. The time required to expose a negative would become shorter throughout the Zangaki's career. Chemists and photographers themselves were constantly improving upon the speed of silver's sensitivity to light. I have observed some blurry pedestrians in a few Zangaki views; however, their images overwhelmingly freeze movement, pointing toward their use of fast exposure times of around one second or less. A good example of a bustling scene frozen by the camera is this bazaar view in figure 12 . 


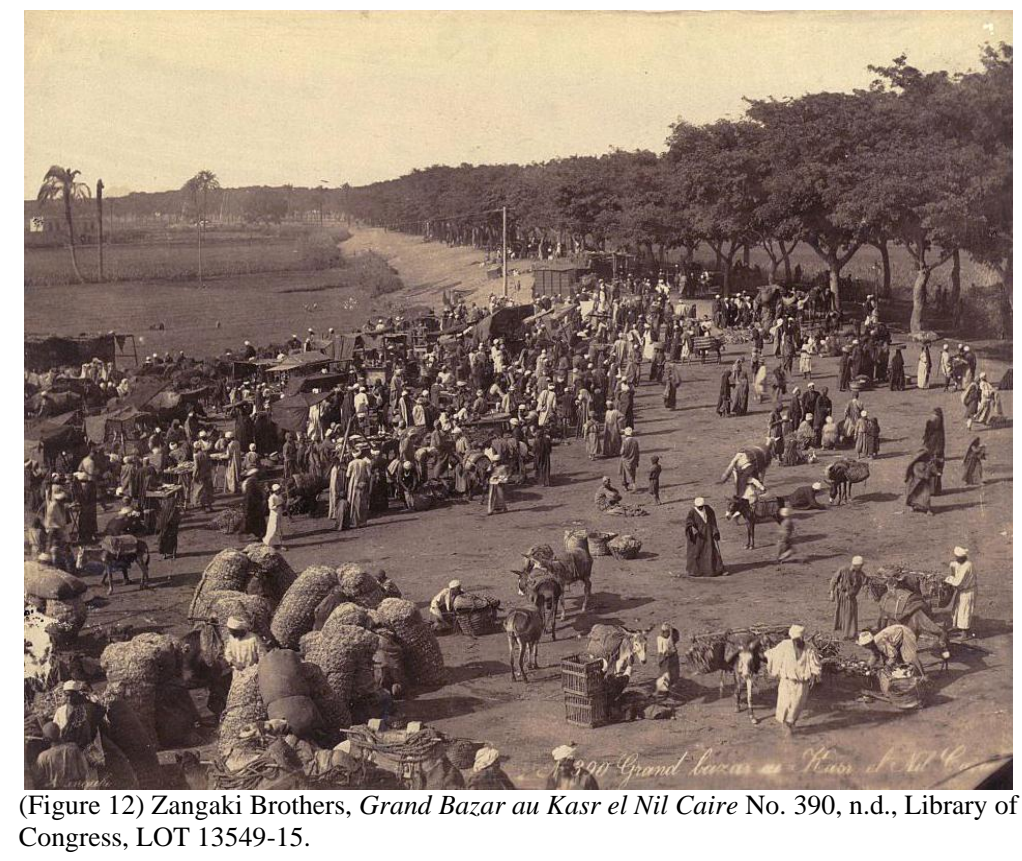

It is probable that from 1870-1879 they used the wet-collodion technique, the dominant negative process from $1851-1878 .{ }^{33}$ This theory is supported by a 1870 s Zangaki photograph in the collection at the Art Gallery of Ontario, of a darkroom wagon with the advertisement, "Adelphoi Zangaki” (Zangaki Brothers) painted on the side. In this image, the wagon is parked in the shadow of the Sphinx. After Nissan Perez first wrote about this mobile darkroom in Focus East, most biographies subsequently made an obligatory mention of it. The wagon, however, was employed only as long as the Zangaki brothers needed to make wet-collodion negatives. Invented by Frederick Scott Archer in 1851 , the process required the negative to be wet with sensitized collodion upon exposure, and developed immediately thereafter in a darkroom while still wet. This was a difficult challenge, and a testament to the dedication and skill of photographers at the

33 María Fernanda Valverde, Photographic Negatives: Nature and Evolution of Process (Rochester, N Y: George Eastman House, 2005), 9-14. 
time who were successful in making a negative. Francis Frith recorded that the collodion actually boiled in his darkroom tent while he was photographing in Egypt. ${ }^{34}$

By 1879 commercially manufactured gelatin dry plate glass negatives were being sold worldwide. ${ }^{35}$ These plates of different sizes: 4x5", 5x7" and 8x10", needed no preparation, the photographer needed only to place them in the camera for exposure. He did not require a nearby darkroom stocked with water and chemicals, adjacent to the scene where he was shooting (near the Sphinx, for example) in order to develop the negative. The dry plate, in turn improved the ease of production and the quality of negatives. I examined Zangaki prints at George Eastman House with nineteenth century glass plate negative expert Mark Osterman. By the marked absence of clues to the wetcollodion process such as "comets" of dust streaking throughout the sky or wavy streaks left from pouring wet collodion, Osterman was able to determine with relative certainty that the Zangaki prints were made from the commercially uniform gelatin dry plate negatives. The widespread use of dry plate negatives corresponds to the period in which they were most productive, from the late 1870 s through the late 1880 s. The Palestinian Exploration Fund in London, which has the only known holding of Zangaki negatives, classifies their 29 negatives as gelatin dry plates. The negatives are of course of Palestine, and consist of the later negative numbers, from 1005-1356.

The last step in preparing the negative would be to varnish it, to protect the image from scratching and peeling and finally applying the signature and title. According to Osterman, the scripted signature and titles would be written backwards in India ink.

34 Marie-Cecile Bruwier and Alain D’Hooghe, The Great Pyramids of Giza (Paris: Viol, 2000), 22.

35 María Fernanda Valverde, Photographic Negatives: Nature and Evolution of Process, 15. 
Whomever the Zangakis employed to execute this challenging task was extremely skilled, since the script on their negatives is elegant and uniform.

Back at the studio in Port Said, the brothers would get to work printing their negatives. They most likely hired assistants to help print the thousands of photographs they made in the darkroom. All of the Zangaki photographs in the collection at George Eastman House are on albumen paper. Albumen paper is a thin, smooth, commercially manufactured paper coated with a solution of salted egg whites. ${ }^{36}$ The main European source of albumen, the nineteenth century's most popular photographic print medium, was the huge chicken factories in Dresden that provided the supply of eggs. Just before exposure, the paper would be light-sensitized with a silver solution. While exposing the sensitized albumen paper to light, the paper and negative are placed flush together. This results in an image that is the exact size as the negative, 8 " 10 " in our case. Albumenized paper proved to be a good match for glass plate negatives (both wet collodion and dry silver gelatin), as opposed to the textured and softer aesthetic of earlier salted paper prints. Albumen paper replicated the sharpness and detail of a glass plate negative on a smooth, glossy surface, a characteristic sought after by most photographers and consumers of this era. Albumen waned in popularity after commercially produced silver gelatin paper came into use in the 1890s. I have observed two silver gelatin prints made by the Zangakis, one at the Harvard Fine Arts Library Special Collections, and one I purchased from EBay. Their signature is on the print and after discussing the physical characteristics with process expert Grant Romer, Director of the Advanced Residency Program in Photograph Conservation at George Eastman House, we concluded these

36 Jim Reilly, Care and Identification of 19th-Century Photographic Prints (Rochester, NY: Eastman Kodak Co., c1986), 5. 
prints were most likely made in their Cairo studio in the early 1900s, before the death of Konstantinos.

The albumen prints are all gold-toned, giving a purple hue to the images. Gold toning is the next step after image-development, when the silver image is "partially converted to gold by treatment in a solution containing gold chloride."37 Toning was employed primarily as a stabilizer; gold-toned photographs do not fade or yellow as rapidly as untoned prints do. These albumen prints were then sold unmounted to the traveler, who eventually would bring the photographs home and compile them in an album as a chronological record of their journey. These albums and often the remaining fragments of albums are precisely what comprise the Zangaki photograph holdings at George Eastman House.

\section{Zangaki Photographs in the George Eastman House Collection}

\section{VIEWS: EGYPT}

The most common method used by art museums to organize their collections is to classify under the creator's name. George Eastman House uses this method and therefore the photography archive is organized by photographer's name. There are exceptions to this rule and in studying the Zangaki brothers I became familiar with a few of these exceptions. The first is albums, of which there are hundreds in the collection that are stored by size and the year they were accessioned. Secondly there are sections designated by subject, one of which is called "Views," into which miscellaneous landscapes are stored and organized geographically. It is in the albums and miscellaneous views that the GEH holdings of Zangaki brothers are stored.

37 Jim Reilly, 5. 
The first group I examined comprised twenty-six photographs in a box titled Views: Egypt in the section of views organized geographically. There are roughly 50 other photographs in Views: Egypt by contemporaries of the Zangakis including the Abdullah brothers, Hippolyte Arnoux, G. Légakian, G. Sarolides, Henri Bechard, Alexandre Dumas and the photographers of the American Colony of Jerusalem. The prints are albumen or early gelatin silver from the mid nineteenth to early twentieth centuries. Most of the prints are mounted and protected within polyester sleeves. A few are specially matted as if for an exhibition, and some are unmounted and are in a polyester sleeve supported with a backing board.

The Zangaki brothers photographs in Views: Egypt are divided into five groups, or lots. ${ }^{38}$ I will describe the lots in chronological order by year of accession. The first of these, lot 1981:2125, came from an unknown donor and a second, lot 1981:2126, is from the collection of Alden Scott Boyer. The Boyer Collection, as it is called, is one of the core collections at GEH. Boyer was an ardent photography collector who donated his entire collection to GEH in $1950 .{ }^{39}$ It is likely he acquired the Zangaki photographs in a bound travel album. The prints were crudely cut from their album by him or by their previous owner in order to sell them individually or for framing.

The photographs in both these lots are mounted on the same type of khakicolored, sturdy board that has aged uniformly. They were cut from an album in the same haphazard manner, are roughly the same size and the prints have also aged uniformly. This leads me to speculate that the unknown donor of lot 2125 was in fact Boyer. Viewed

38 The first two lots are 1981:2125:0001-0014 and 1981:2126:0001-0007. The prefix 1981 designates the year the objects were accessioned into the collection. The lot numbers are 2125 and 2126. Lots usually indicate the donor or the provenance of the objects. 39 A Collective Endeavor: The First Fifty Years of George Eastman House (Rochester, NY: George Eastman House, c1999). 
together, the two lots appear very similar. It is possible that before being placed into Views: Egypt, the prints were stacked in separate piles in physically opposite parts of the archive, causing their original connection to be missed by the catalogers in 1981 . Therefore 2125 was attributed as unknown and 2126 as Boyer. They are all images of the Nile and Cairo and there are no duplicate scenes, a further indication they were previously from one album, telling the story of one traveler's trip to Egypt.

Well over a century old and having traveled across oceans, the twenty-one Zangaki photographs from lots 2125 and 2126 are in remarkably decent condition. They uniformly exhibit the typical yellowing edges found on early albumen prints. Curiously, these prints were all made on paper that was tinted pink. Some of the papers are a deeper pink than others, indicating the Zangakis may have been experimenting with different dye saturations. Regardless, a pink tint is discernable in all the photographs in these two lots. Mark Osterman elaborated on tinting while looking at these prints with me. He said that tinting was common. As silver oxidizes and the highlights fade over time, a paper tinted with pink dye will appear to age more gracefully and not end up such a sickly yellow. This also supports the probability that these lots were printed in the Zangaki studio around the same time. The same batch of pink paper, similarly yellowed edges and uniform tone of the prints indicate a consistent pattern in the photo chemicals and gold toning process of these images.

Many of the prints exhibit a horizontal cracking in the emulsion, suggesting they were purchased and brought home as rolled prints and mounted into an album after the trip. This is precisely what the Baedeker guidebook for travelers to Palestine and Syria suggested to tourists in 1876. "Shapira, Christian Street, is the best shop [for] 
photographs of every part of Palestine, medium size, 18 fr. Per dozen. They should be bought unmounted, and rolled on a round piece of wood to facilitate transport." ${ }^{, 40}$ Osterman explained that a striated, horizontal cracking visible in albumen is evidence of a once tightly rolled print. Another commonality between the two lots is the appearance of brushstrokes in the skies, revealing where glue was applied to mount the print to the board. The appearance of these brushstrokes in all the images with sky indicates that a similar adhesive and application technique was used in both lots.

The content in lots 2125 and 2126 includes panoramas, mosques and street scenes of Cairo as well as different views of the Nile. It suggests the traveler took a boat ride up the Nile and spent time in Cairo, prompting him or her to purchase photographs that exemplified this experience. There are a few images of note in the lots. 1981:2125:0005 Exportation dans le Nil, No. 618 reveals a technical strategy employed by the brothers. Since the print has faded we can now see a mask they painted on the negative. It was painted to lighten the reflection of the boat pictured in the Nile, possibly to show more detail in the reflection. It also appears that they painted out the sky in this negative as they did to the skies of their other landscapes. According to Osterman, this negativepainting strategy was used by every wet-collodion and by most dry plate photographers. Because of their high sensitivity to UV light, these early negatives did not capture clouds. Blue and white light exposes the silver at the same value in negatives. Skies were basically blank canvases through which every flaw of the negative and processing could be seen. Collodion often dried streaky or dust particles would embed in the sky and print clearly onto the photographic paper. Photographers, therefore, invented a method of

40 K. Baedeker, ed., Palestine and Syria, 145. 
masking their tracks and utilized red oxide paints to block out the entire sky. The final print would produce a uniformly blank, cloudless vista, that we are used to seeing in landscapes of this era.

Certainly there were some fastidious photographers who combined two negatives in order to add clouds to their stark landscapes. The first successful attempts at "combination printing" are usually credited to Gustave Le Gray in the mid-1850s. ${ }^{41}$ Combination printing would not be a cost-effective technique for a busy commercial studio like the Zangaki's. They were occupied with mass-producing images for the bustling tourist trade.

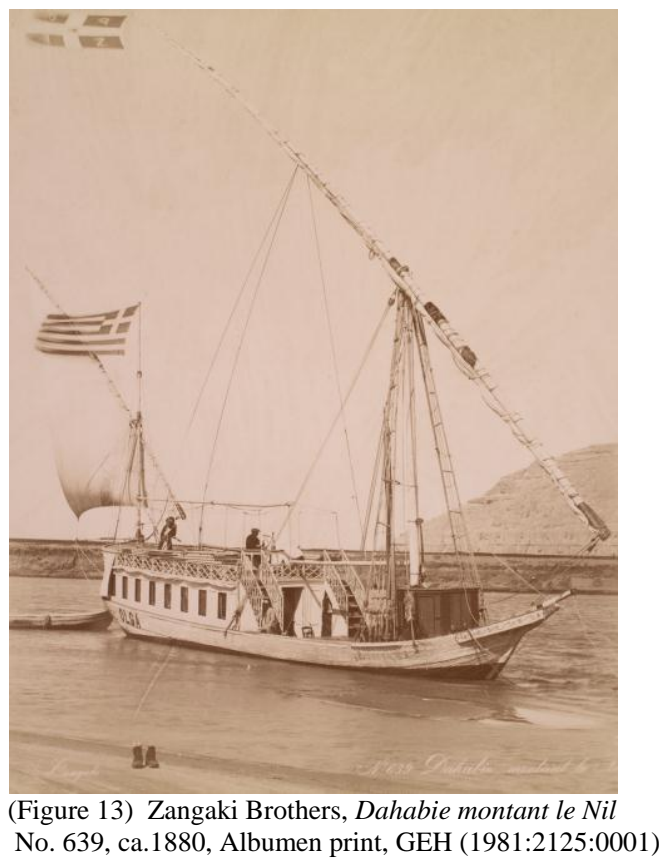

Another photograph of note in lot 2125 is Dahabie montant le Nil, (figure 13). As mentioned earlier, a Dahabie, or, more commonly, Dahabieh, is a Nile River cruise boat, built for comfort ${ }^{42}$. This particular one has a cast of characters lounging aboard with the

41 Newhall, 74.

42 Grant Romer, in conversation with the author, April 2009. 
Greek flag flying and the name $O L G A$ painted along the side. It is possible that this Dahabieh was named after the Queen of Greece. Olga Konstantinovna of Russia married George I (the Danish king of Greece) in 1867. One of their daughters, who died at three months old in 1881, also was named Olga. ${ }^{43}$ So it is also possible that the baby Olga may be intended as the boat's name. If this is the case, the photo could be dated to after 1881 . The Greek flag leads to my speculation that this is the Zangaki's boat, or at least their rented boat for the journey. A man on the top deck, wearing a flat cap and western clothes, double fists two bottles while a hookah waits in front of him. He is at the head of the boat and is the focal point of the composition, signifying that he is the captain of the outfit. The other man on top deck appears disheveled while he leans back on a rope. He has wild hair, a beard, wears a robe, and looks Western. The third man wears Arab clothing and does not seem to be having a good time as he tries to avoid the sun while sitting on the stairs. Prominently displayed in the foreground on the shore are a pair of boots, suggesting the photographer took them off and carried them as he forded the river with his camera equipment in order to make this shot. It also indicates he was going to need the boots after making this record of $O L G A$, possibly to hike along the riverbank and make more plates. Did the crew join him after this shot? The effort put forth in this staged document reveals the pride the Zangakis must have had in their outfit. They are affirming their claim in the Levant, anchoring on the banks of the Nile, their presence in this historic landscape confirmed.

43 Dr. Nikos Kokkinos, e-mail message to author, April 3, 2009. 


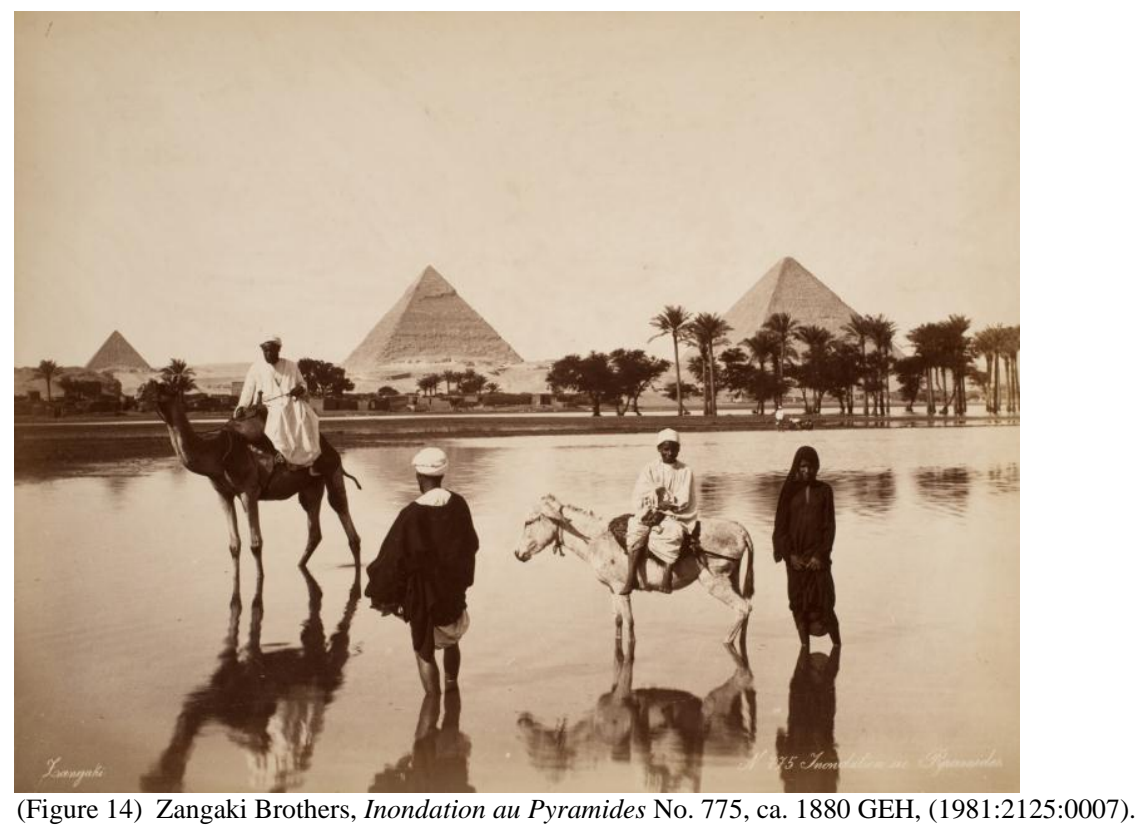

The Zangaki's Inondation au Pyramides No. 775 is a striking and beautiful image.

In this and other pictures they employ the use of reflections in the Nile as do Maison Bonfils and Légakian. What distinguishes the Zangaki image is its use of figures in the foreground. They create a rhythm as the second person from the left faces toward the pyramids while the other three figures face the camera. The sway in the stance of the female at the far right dreamily beckons the viewer. These two mysterious people in the image transform it from a simple reflection of the pyramids into a quiet, serious and elegant depiction of the native people of the Nile.

At some point during this print's life at GEH it was selected for display. It is one of two Zangaki prints in Views: Egypt that are framed with an over-mat and protected with tissue paper. Inondation au Pyramides is still mounted on the same irregularly cut board as all the other Zangaki's in lots 2125 and 2126 . It was most likely selected to be in an exhibition for the aesthetic qualities I noted above, and was therefore framed. 
One irregularity in these lots is Partie del Caire el Mosquee Hassan No. 153. This architectural photograph is found in the Middle East: Types box. Although this is a view of a Mosque in Cairo and should therefore be in Views: Egypt, on the reverse of Mosquee Hassan is a mounted photograph of a Turkish woman, a type. It is titled Dame Turque by L. Fiorillo, an Italian photographer based in Alexandria. According to GEH Curator of Photographs and Director of PPCM, Alison Nordström, it was common practice for travel albums to have a section on types, studio portraits of "typical" native people, inserted toward the end of the album after the landscapes and views. ${ }^{44}$ The archivist who made the selections for the box titled Middle East: Types chose Dame Turque to be included as a type. Mosquee Hassan, mounted on the reverse, inadvertently tagged along. This Zangaki print has been lost in the shuffle, sacrificed for the preference given at one point in time to a Dame Turque over a Mosque in Cairo by an archivist.

The next two lots in Views: Egypt are 1983:1317 and 1983:1345 and were donated by the noted photojournalist Pirkle Jones. According to the GEH registrar's records, Jones donated 20 mounted photographs and an album of photographs to the Museum in July of 1960. Four of these 20 mounted photographs are by the Zangakis. The other mounted prints are from the same era, by Giacomo Brogi, L. Fiorillo or unknown makers. In these lots, the four Zangaki prints are presented with much more formality than those in the previous two lots. Mounted singly on high quality, heavy mat board with rounded edges, they appear to be meant as exhibition pieces, not to be hidden away in an album. The images are elegant, balanced compositions of palms along the Nile,

44 Alison D. Nordström, in conversation with the author, Fall 2008. 
women on donkeys and a panorama of Cairo. In considering aesthetics and content, these images rise to the top.

One of the four mounted Zangaki photographs is mounted on a deep marooncolored mat while the other three are on tan mats. There is evidence of severe striated cracking in a diagonal direction on three of the four prints, the usual indication they were rolled and mounted once back home. There is no pink tint visible in the paper, though this does not necessarily indicate there was no dye used. According to Osterman, the dyes faded easily when exposed to light for prolonged periods of time. As they are individually mounted on exhibition quality mat board and show fading and yellowing throughout, I believe they were displayed at some point and the dye along with some of the silver, once visible, has now succumbed to light fading. It is possible Jones inherited these prints from relatives who traveled to Egypt, or that he bought them as curiosities. Either way he considered GEH a suitable repository for these four prints.

The final Zangaki photograph stored in Views: Egypt is Chadoufs de la Haute Egypte No. 630, part of a gift from Christina Oddleifson. The image depicts men working at a well, drawing water up from the Nile for irrigation. The Library of Congress also has this print and as previously mentioned, the Zangakis reproduced it as a collotype postcard at the turn of the century (see figure 8). There were many photographs of irrigation wells made during this period, suggesting it was a favorite tourist subject. The scientific and industrial mind of the time was no doubt intrigued by this primitive irrigation system used along the Nile. (Curiously, this type of system is now being considered by European nations as a sustainable irrigation method). ${ }^{45}$

45 http://www.shaduf-eu.org/ 
This is the second Zangaki photograph in Views: Egypt that is housed in a modern, exhibition- quality overmat. It is framed in the French style called montage évidé, a technique used by conservationists to display unmounted albumen prints. The print is unobtrusively attached along its edges to rice paper that in turn is adhered to the window opening of the mat. This allows the front and back of the print to be viewed while keeping the print unrolled and presentable. Chadoufs de la Haute Egypte exhibits excessive horizontal cracking in the emulsion and is faded and yellow throughout. Perhaps it had been rolled right up to the point it was treated with a montage évidé.

According to the acquisition records for this lot it was a "drop and run" gift from Christina Oddleifson, a resident of Rochester. Seventeen photographs from the two tattered albums with loose prints that comprise this lot were donated to conservation for "educational purposes." ${ }^{\text {"46 }}$ I believe Chadoufs de la Haute Egypte was one of them, accounting the use of the montage évidé and the fine-quality overmat. There is one other Zangaki photograph in this same Oddleifson gift, though it is not stored in the Views: Egypt box. It is in one of the two fragile albums described above in the "drop and run" gift. The album is made of heavy gray construction paper with brittle and yellowed waxpaper interleaving. It appears to be handmade. Included are photographs of Cairo and the Pyramids by Maison Bonfils, Sébah and Légakian. All the photographs are in poor condition, showing signs of fading and yellowing. The Zangaki image, Laggeh Egyptiene No. 540, is in the worst condition of all the prints. It is severely yellowed with fading and density loss throughout. This may point to a lack of thorough processing and washing by the brothers. Perhaps Ms. Oddleifson and whoever originally made the album stored it in

46 Stacy VanDenburgh, Memorandum from Assistant Registrar to Collection Records, "Bizarre accessioning of Oddliefson gift", (George Eastman House, April 5, 2001). 
a location with high humidity and temperature levels, causing the excessive deterioration. One of the Maison Bonfils photographs in this album, of tourists climbing the Great Pyramid, shows graffiti carved in a rock. It reads, "G Zangaki” (figure 15).

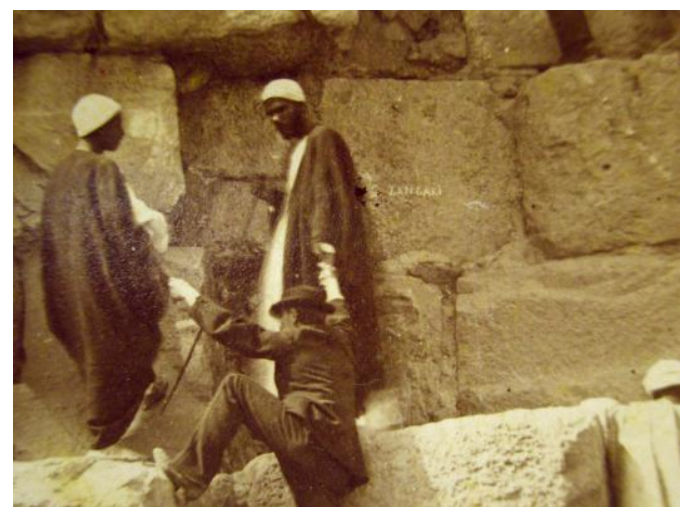

(Figure 15) Maison Bonfils, Climbing the Pyramids, ca. 1880 GEH, (2000:0814).

Joe Struble, photography collection manager at George Eastman House, discussed with me the storage decisions he made roughly fifteen years ago concerning Views: Egypt. He began by reviewing the fact that the box comprises travel views made by different photographers. The catalog records for these images have not been "cleaned up" or dealt with. Rather than creating individual photographer boxes, into which the rest of the GEH collection is organized, the collection manager at the time, David SouresWooters, and Struble decided to store these views together in one box. This decision was based on their belief that the strength of these photographs lies in the subject matter rather than with the individual photographer. As previously stated, this is a departure from the traditional method of organizing by artist. However, Struble and SouresWooters made their decision based on the concept of accessibility from a researcher's point of view. Researchers, they believed, were more likely to come into the archive and ask to see views of nineteenth century Egypt rather than photographs by the Zangaki brothers. As Struble explained, it was a matter of access. 
According to Struble, the researchers most likely to request the Views: Egypt box are those with academic interest in the Grand Tour. He was quick to note that many of these researchers are on what he calls the "point the finger bandwagon." "They are looking for evidence of the Western Gaze confronting exotic cultures. These researchers are curious about how Near East people were portrayed and are often outraged and selfrighteous about the photographs before even looking at them," said Struble ${ }^{47}$. This view, reminiscent of Edward Saïd's accusatory angle in his critique Orientalism, is, one hopes, becoming outdated. $^{48}$

This mixed-box storage decision highlights the Zangaki's obscurity. But Why have they been neglected? The manner in which these photographs are stored is both a reaction to and a perpetuation of the fact that the Zangaki brothers hold no weight in the Near East commercial canon. Had there been a Maison Bonfils photograph of the same quality and subject in Views: Egypt, it would surely have been cherry-picked out and placed within a "Bonfils" box. There are certainly enough Zangaki photographs in the mix to warrant their own box. Yet they are shuffled into this grab-all box because of their third-tier status, and it is here they remain, their place in the miscellaneous box continuing their legacy as yet another secondary tourist outfitter from Egypt. This is analogous to the storage decision Struble mentioned that he and Soures-Wooters made for "Native American portraits". The Edward Curtis portraits had been separated out and placed in their own box, while every other studio or individual photographer is grouped into a Portraits variety box. Of course there is not enough time, space or money at GEH to have an individual box for each photographer. But why do Maison Bonfils and

47 Joe Struble, in conversation with the author, January 2009.

48 Edward W. Said, Orientalism (New York: Pantheon Books, 1978). 
Arnoux, for example, have their own box, and not the Zangakis, is ultimately the question. The same situation exists in other collections around the world, as the Maison Bonfils and Arnoux studios are decidedly the historically recognized ones from the era. In his book Masterpieces of Photography: From the George Eastman House Collections, the only Near East photograph Robert A. Sobieszek includes is one by Maison Bonfils of a young boy resting on a broken column. ${ }^{49}$ We therefore understand the Maison Bonfils picture to be the sole masterpiece of Near East photography.

\section{Charles Wilder Gorton Album}

Besides the Views: Egypt box, GEH has Zangaki photographs in souvenir albums and portfolios. The photographs are bound or arranged in their original context, parts of a larger group of photographs that document the different places the traveler visited.

The earliest accessioned album at George Eastman House that contains Zangaki photographs is an elegant but worn, heavy red-leather album with a patterned gold-leaf embossed border that belonged to Charles W. Gorton (1855-1930) of Rochester, N.Y. Gorton was born into wealth as a son to the president of Flour City Bank (later National Bank of Rochester). ${ }^{50}$ The cover bears a title stamped in gold leaf: THE

\section{MEDITERRANEAN JAFFA - ALGIERS 1895.}

Charles Gorton would have made his voyage en Orient at age 40 , when he traveled in the Holy Land up to Constantinople, ending his journey in Tunis and Algiers. The pastedown and end-papers of this album are beautifully marbleized and multicolored, a popular trend for photographic albums in the 1890s. There are roughly 120

49 Robert A. Sobieszek, Masterpieces of Photography: From the George Eastman House Collections (New York: Abbeville Press, 1985).

50 William Farley Peck, History of Rochester and Monroe County (New York: The Pioneer publishing company, 1908 ), 928. 
brittle, warped, originally cream-colored but now yellowed, two-ply pages in this album, each with a photograph mounted on the right-hand page. The first seven pages of the album are still bound, the next 80 or so have been carefully sliced out by a conservator and the remaining ten pages are still attached to the binding material.

Twenty-eight of the Gorton album photographs are by Zangaki and they comprise the first section: Views of Jaffa, Jerusalem and Bethlehem; (there are twelve photographs interspersed with the Zangaki's that are unidentified). Immediately following this group is a Maison Bonfils view of Smyrna, a Sébah of Smyrna, a dozen or so views of Constantinople by Gulmez and Abdullah Frères and many of Tunis and Algeria marked as unidentified. The album is completed with portraits of "types" from the regions Gorton visited.

This album was originally cataloged by 2007 PPCM graduate Maryam Ghorbankarimi. The catalog records in TMS listed seven prints with the Zangaki signature as unidentified. With permission from GEH registrar Wataru Okada, I changed the photographer "unidentified" to Zangaki and added the dimensions for all the Zangaki images in this lot.

Gorton arranged his album to illustrate his journey and he wrote the dates of his visit to each location pictured. All of the Zangaki prints have a BFK Rives $\mathrm{N}^{\mathrm{o}} 74$ blind stamp, identifying it as the popular French paper used for albumen. I don't believe these prints were tinted with pink dye; nor were they gold-toned especially well since they exhibit severe yellowing.

Notably, there are several interior shots of churches that required the use of flash. At this time, the brothers would have employed the blinding magnesium flashlight 
powder $^{51}$ that created the strong shadows and contrast in these images (figures 16 and 17).

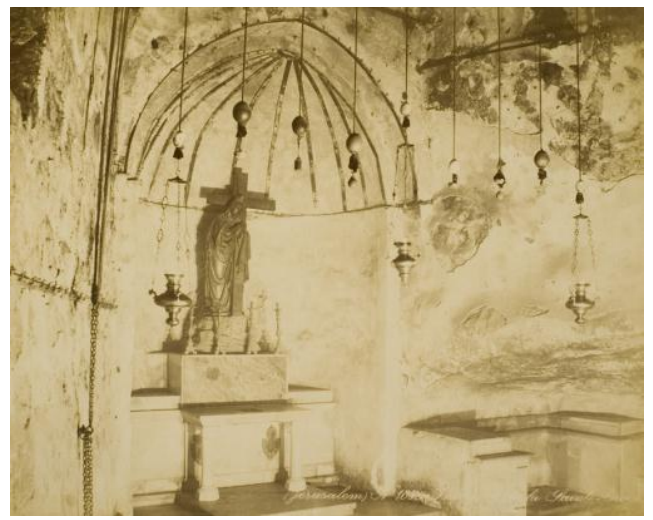

(Figure 16) Zangaki Brothers, (Jerusalem) Interieur de la de la Sainte-Croix No. 1095, c. 1895, albumen print, GEH (1973:0230:0009).

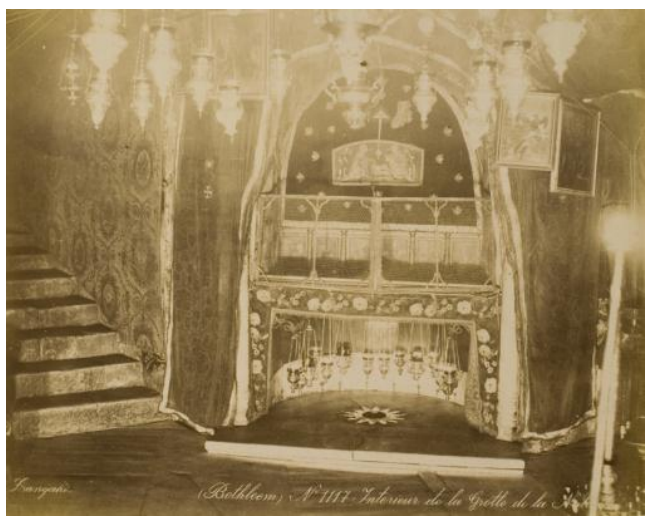

(Figure 17) Zangaki Brothers, (Bethleem) Interieur Grotte de la Nativitie No. 1117, c. 1895, albumen print, GEH (1973:0230:0033).

Compared with the other photographs in this album, the Zangaki brothers'

photographs function as landscapes of the Holy Land and less as architectural views or portraits. Landscape work is their aesthetic strongpoint, and this album highlights this well with images like that in figure 18.

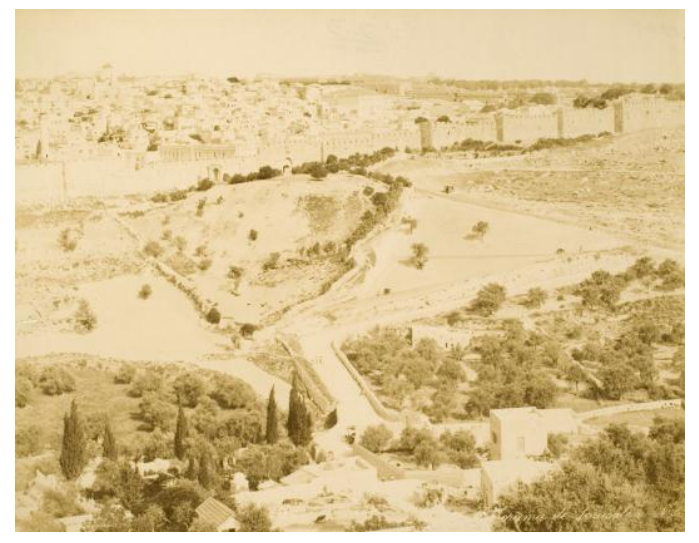

(Figure 18) Zangaki Brothers, Panorama de Jerusalem, c. 1895, albumen print, GEH (1973:0230:0015).

The composition features a strong diagonal that leads the eye from the cypress and olive trees in the foreground, through a barren field of the mid ground, across to the walled city of Jerusalem in the background. It is a sophisticated and pleasing way to 
organize this landscape, in which the earth takes up seven eighths of the composition, the sky an even swath across the top.

\section{James Sibley Watson, Sr. and Edmund Lyons Portfolios}

Two portfolios originally belonging to James Sibley Watson, Sr. and Edmund Lyons are souvenirs from a journey made by two friends. A portfolio is distinct from a traditional album in that the group of mounted prints is not bound. Portfolios are a later style of presentation than the heavy leather bound albums ${ }^{52}$ and make it possible to easily frame and display individual photographs.

The Watson portfolio has a front and back cover made of brown woven fabric with gold-trimmed, red-leather corners and marbleized pastedown and end papers. It is stored with other albums of the same size in the photography vault at GEH. The portfolio was a gift made in 1978 by Dr. James Sibley Watson, Jr. (1894-1982), a doctor from Rochester who experimented with early motion pictures. ${ }^{53}$ Beginning in 1949 he made many gifts to the Museum over the years, mostly motion picture related. The photography gifts Watson made include seventeen Zangaki photographs that are in the portfolio and eighteen other travel and early snapshot albums from the late nineteenth

century. ${ }^{54}$ As these albums and the portfolio date from an earlier generation, I surmised that Watson was handing over his parents' photographic albums for posterity to George Eastman House.

The second portfolio of prints that includes sixteen Zangaki photographs is part of a gift to the museum from Eugene Van Voorhis that contained more than 500 nineteenth

52 Joe Struble, in conversation with the author, January, 2009.

53 Bonnie Costello, ed., The selected letters of Marianne Moore (New York: Knopf, 1997), 570.

54 Registrar records, 1978:1297-1315, November 7, 1978, George Eastman House. 
century travel views. According to a brief description of the gift written by GEH intern Elizabeth M. Stauffer, Van Voorhis donated his grandparents' (Edmund and Carol Lyons) collection of travel albums, and is therefore aptly titled the "Edmund and Carol Lyons Collection.” The Lyons' were a prominent Rochester family whose personal papers are held at the University of Rochester Manuscript and Special Collections archive. In box XVI of the Lyons Collection, marked "Misc. notebooks and papers", I found a "List of Passengers" for the R.M.S. UMBRIA, from Liverpool to New York, June 22, 1889. Among the passengers listed are 'Mr. E. Lyon' and 'Mr. George Watson, Jun.'

I have been unsuccessful in determining who exactly George Watson, Jr. was, though he most likely is related to the donor James Sibley Watson, Jr. That is how the portfolio from his voyage en Orient ended up at George Eastman House. It seems clear that Edmund Lyon and George Watson were friends from Rochester, traveled abroad together, and while in Egypt, selected 33 Zangaki prints (as well as ones by other photographers) as souvenirs. Edmund would have been 34 on this trip, and according to the write-up by Stauffer, "Before his marriage... he visited the Holy Land with friends, traveling to places mentioned in the Old and New Testaments... $)^{55}$ I imagine Stauffer interviewed Eugene Van Voorhis to obtain this illuminating biographical information about his grandfather.

The Watson portfolio was uncataloged, so with registrar Wataru Okada's help, each page in the album was given an individual record in TMS. I next added the constituent, date, medium, dimension and title for each Zangaki photograph. I also

55 Elizabeth M. Stauffer, Edmund and Carolyn Lyons, George Eastman House collection records, 2003. 
arranged for GEH collections photographer Barbara Galasso to digitally photograph the Zangakis (1978:1297:0015-31), as well as the rest of the photographs in the portfolio.

The Lyons portfolio was partially cataloged, seven of the 16 photographs had a record in TMS. Okada added the records and I again cataloged the pertinent information for each print into TMS. Galasso also digitally photographed all 16 photographs.

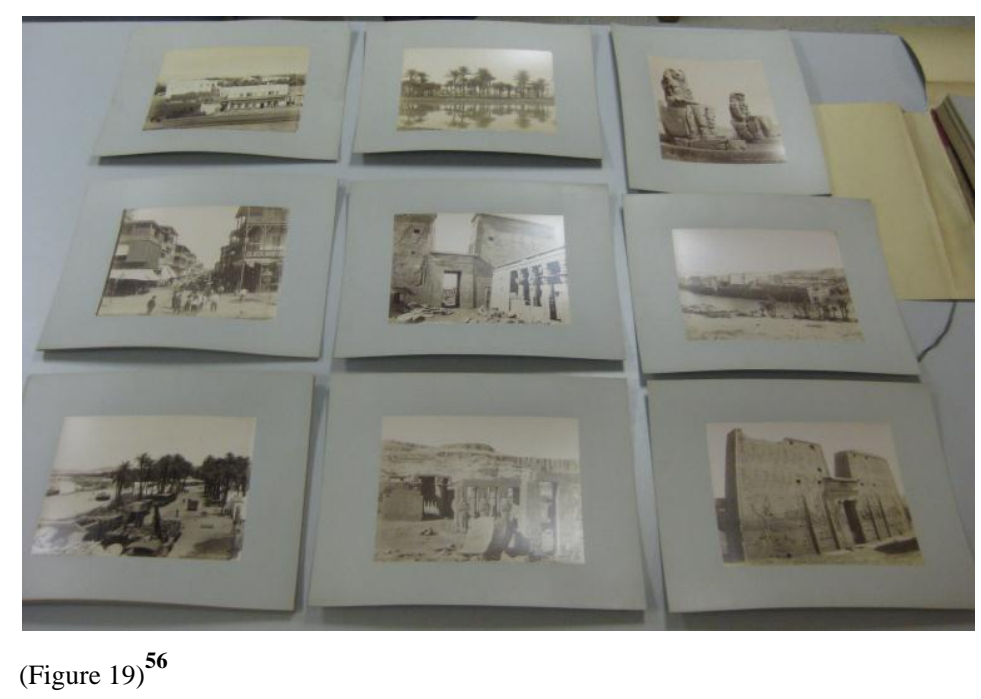

Viewed together, the Watson and Lyons portfolios are remarkably similar. Figure 19 above shows a selection of photographs from both portfolios. No two prints are the same even though Lyons and Watson each chose architectural views of the ancient temples along the Nile, pastoral Egyptian scenes and one view of Port Said. They must have taken a Nile cruise themselves, and stocked up on souvenirs in Port Said before returning to their Mediterranean steamer. The uniform size, shape and gray color of the boards on which the photographs are mounted suggest the men had them mounted at the same shop.

56 A selection of Zangaki photographs from two different portfolios at George Eastman House (1978:1297 and 2001:1522). 
The prints are tinted pink and a careful study of them highlights the commercial nature of the Zangaki brothers' enterprise. There is evidence that these are mass produced, with some negatives printed slightly at an angle on the paper, exposing a black corner. A few prints reveal areas where chemicals pooled on the paper edge, leaving stains. Some prints were not toned in gold well enough and have yellowed more than usual. White circles in several prints show where silver never took to the paper. All of these little markings describe a busy studio that had hundreds of prints exposing in the sun, coated with chemicals and hanging to dry all at once, leaving room for error. These technical imperfections are not unique to the brothers, but the selection made by Watson and Lyons in 1889 has a large number that reveals the mass-produced origin of these prints. The year 1889, when Lyons and Watson took their tour, may well have been the apex of the Zangaki studio success.

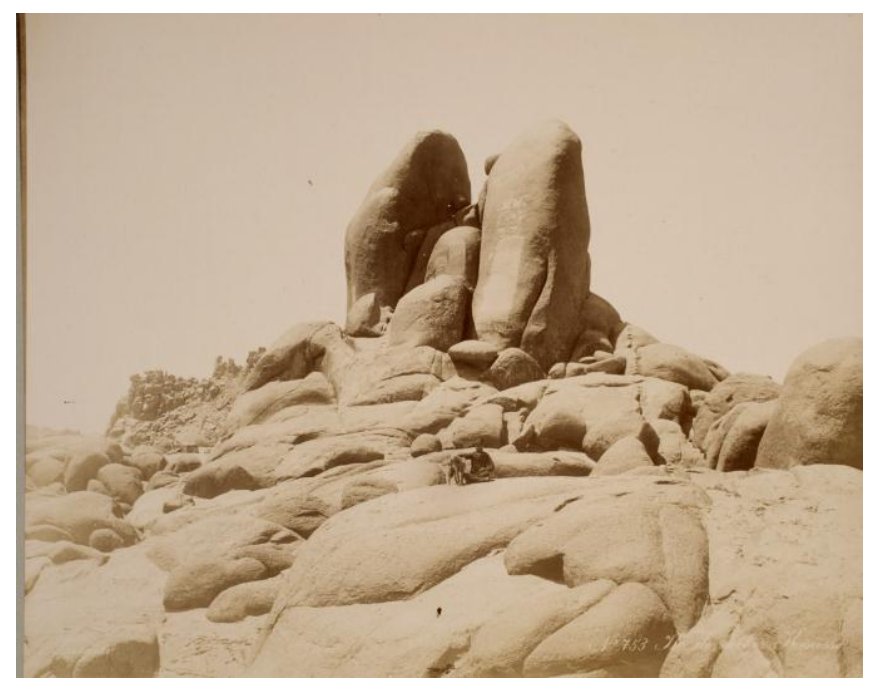

(Figure 20) Zangaki brothers, Ile. de rocher Konosso No. 753, ca. 1880, albumen print, George Eastman House (2001:1522:0003).

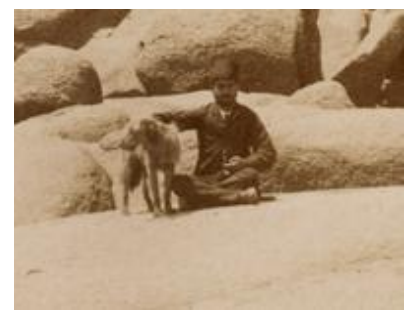

(Detail of fig. 20)

Above is the most intriguing image from the two portfolios. Seated just below huge boulders with ancient Egyptian inscriptions, one of the Zangaki brothers, the same 
one with the jaunty stance in the Port Said street scenes, poses with a dog. The usual explanation for including figures is to provide a sense of scale to the architecture or elements in the scene. This cross-legged figure seated front-and-center, with his right hand on a dog and left palm-up and holding something, reads like a pitcher/catcher signal in baseball. Something is being communicated between the brothers, or perhaps the upward palm signifies something just to the brother posing. He may also be holding a clock marking the exposure time. Regardless, it creates an interesting composition in which the figure becomes part of the rock formation, his presence likely overlooked upon first glance. A more careful study reveals the posed man-and-dog, among the strong shadows and highlights that construct this scene. Also of note in the top left corner is an example of the misaligned negative and paper, exposing a black angle where the negative did not perfectly match up with the paper. Together, these portfolios highlight the commercial nature of the business in which the brothers were engaged.

\section{Mrs. Phil Porter Albums}

In 1986 the family of Mrs. Phil Porter, for whom there is as yet no biographical information, donated four albums from her travels to Europe and the Levant. PPCM graduate (2008) Nadia Kousari wrote her thesis on one of these four albums. ${ }^{57}$ Kousari's emphasis was on Porter's embellishment of her album with captions and descriptions taken directly from Baedeker's Guidebook of the place pictured. Two of the albums contain Zangaki photographs: Berlin to Cairo (1986:0309) and Palestine (1986:0310).

57 Nadia Louise Kousari, Constant Companion: An Analysis of the Use of Baedeker's Guidebooks in Creating a Victorian Photograph Album (Toronto: Ryerson University, 2008). 
Both maroon-colored leather albums exhibit severe red rot. The titles are embossed in gold on a simple cover. Berlin to Cairo and Palestine each have four Zangaki photographs of Cairo and the Nile. There are a few images of Cairo by P. Sébah that appear before the Zangaki's, and are equally non-descript. Porter's selections couldn't be more, "by the book". She has two selections of hieroglyphs, two of palms along the Nile, one fallen statue of Ramses, two unremarkable views of the Suez Canal and finally, the interesting street scene Rue du Comerce $a$ [sic] Port Said described above.

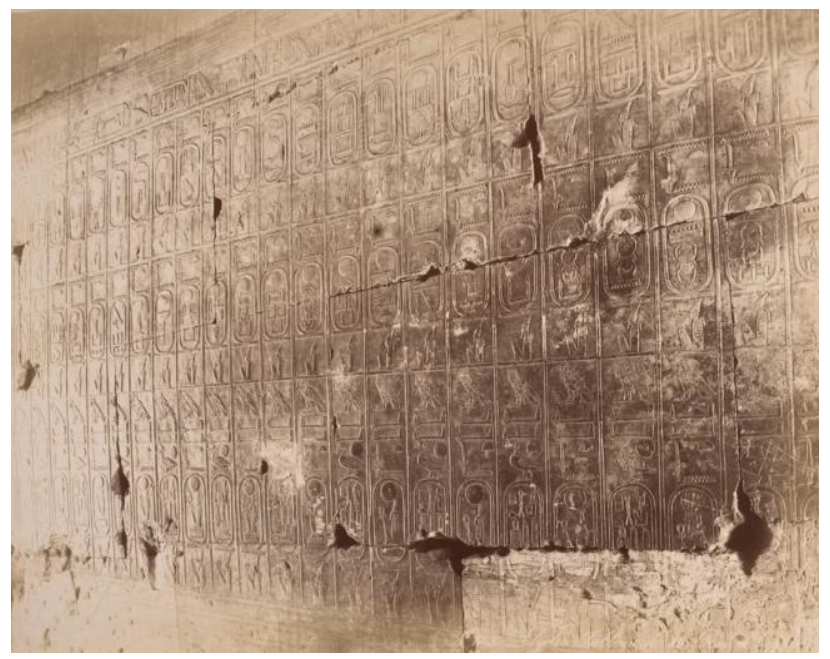

(Figure 21) Zangaki brothers, Abydos Tableau des 76 Rois d' Egypte, ca. 1880, albumen print, GEH (1986:0309:0084).

Particularly well done is the hieroglyph image in figure 21, which is typical of their best work. Shot at an angle, the image would not be especially useful to an Egyptologist attempting to discern the marks. Instead, this view offers a strong designfocused approach, emphasizing the repetition and seemingly infinite pattern that recedes in space. Shooting from an angle instead of straight on is also an intelligent way to use light. The light hitting the inscriptions from an angle emphasizes contrast in shadow and highlight, the most effective way to see the topographic of the wall. 


\section{Edward Lennert Lantern Slides}

The final group of Zangaki images to be found at George Eastman House is in a group of lantern slides donated by Edward Lennert of Rochester. I was unable to find any biographical information on Lennert other than his Rochester address.

In 1987 Lennert donated 5,095 lantern slides to the Museum. Seven of the 5,095 lantern slides are ones by the Zangaki brothers. Lantern slides are positive images on $3.25 " \mathrm{x} 4$ " glass plates. They are intended to be projected onto a screen, lit from behind by a light source and were the precursor to the modern $35 \mathrm{~mm}$ slide and today's PowerPoint images: used for entertaining, educating or lecturing groups of people.

These slides may have been made from a University's collection of Near East photographs to be used in lectures. I do not know enough about the provenance to speculate further on their original use. They are of Zangaki views that I have seen in other collections and a few represented in the GEH collection. Overall they are fine representations of three different ancient monuments, three scenes dal vero and one elegant portrait of a Turkish woman.

\section{Conclusion}

The Zangaki brothers were photographers very much rooted in the commercial tradition. They also, however, demonstrate sensitivity to the medium and a more sophisticated approach to the trade than has generally been credited to them. A strong artistic sentiment and dedication to photography is required to consistently create the aesthetically successful compositions they have made.

The answer to why Maison Bonfils is the decided "Master" of Near East photography may be because of their French heritage, the sheer quantity of their work 
and their earlier arrival time on the scene. The current third-tier status of the Zangakis is also partly explained by the pernicious effect Nissan Perez had after his dismissal of them in Focus East, repeated in subsequent publications on the brothers. These factors combined with scant records left of their business, offer little for researchers to discuss and publish regarding the brothers. The end results are collections management decisions like those made plain at George Eastman House: placement in miscellany Views: Egypt box surrounded by an archive of Masters. 


\section{BIBLIOGRAPHY}

\section{Photography: History, Theory and Technique}

A Collective Endeavor: The First Fifty Years of George Eastman House. Rochester, NY: George Eastman House, c1999.

An den süssen Ufern Asiens: Ägypten, Palästina, Osmanisches Reich: Reiseziele des 19. Jahrhunderts in frühen Photographien. Köln: Das Museum, 1988. (On the Sweet Banks of Asia: Egypt, Palestine, the Ottoman Empire: Travel Destinations of the 19th Century in Early Photographs.)

Antiquity \& Photography: Early Views of Ancient Mediterranean Sites. Eds. Claire L. Lyons, J. Paul Getty Museum. Los Angeles: J. Paul Getty Museum, 2005.

Aubenas, Sylvie and Jacques Lacarrière. Voyage en Orient. Paris: Hazan: Bibliothèque Nationale de France, 1999.

Bull, Deborah. Up the Nile: A Photographic Excursion, Egypt 1839-1898. New York: C. N. Potter, 1979.

Chevedden, Paul. "Making Light of Everything: Early Photography of the Middle East and Current Photomania." Middle East Studies Association Bulletin, Volume 18 No. 2, December 1984, 151-174.

- The Photographic Heritage of the Middle East: An Exhibition of Early Photographs of Egypt, Palestine, Syria, Turkey, Greece \& Iran, 1849-1893. Malibu, Calif.: Undena Publications, c1981.

Debbas, Fouad. Des Photographes à Beyrouth, 1840-1918. Paris: Marval, 2001.

D’Hooghe, Alain and Marie-Cecile Bruwier. The Great Pyramids of Giza. Paris, ViloPublilshers, 2000.

Frith, Francis. Egypt and Palestine Photographed and Described. London: James S. Virtue, 1858-1860.

Jacobson, Ken. Odalisques \& Arabesques: Orientalist Photography 1839- 1925. London: Quaritch, 2007.

Johnson, Dr. Samuel. Quoted in George Wilson Bridges, "Selections from Seventeen Hundred Genuine Photographs.” Cheltenham: Mary Hadley, c. 1852.

Kousari, Nadia Louise. Constant Companion: An Analysis of the Use of Baedeker's Guidebooks in Creating a Victorian Photograph Album. Toronto: Ryerson University, 2008. 
Masterpieces of Photography from the Riddell Collection. Introduction by S. Stevenson, catalogue by J. Lawson. Edinburgh: 1986.

Museum voor Volkenkunde. Beelden van de Oriënt: Fotografie en Toerisme, 1860-1900 Images of the Orient: Photography and Tourism, 1860-1900. Eds. Paul Faber, Anneke Groeneveld, Hein Reedijk. Amsterdam: Fragment in samenwerking met Museum voor Volkenkunde, Rotterdam, c1986.

Newhall, Beaumont. The History of Photography. New York: Museum of Modern Art, 1982.

Nir, Yeshayahu. The Bible and the Image: The History of Photography in the Holy Land, 1839-1899. Philadelphia: University of Pennsylvania Press, 1985.

Onne, Eyal. Photographic Heritage of the Holy Land, 1839-1914. Manchester, England: Institute of Advanced Studies, Manchester Polytechnic, 1980.

Osman, Colin. Jerusalem: Caught in Time. New York: New York University Press, 2000.

Perez, Nissan. Focus East: Early Photography in the Near East (1839-1885). New York: Abrams, 1988.

Reilly, Jim. Care and Identification of Nineteenth Century Photographic Prints. Rochester, NY: Eastman Kodak Co., c1986.

Simoën, Jean-Claude. L'Egypte Eternelle: Les Voyageurs Photographes au Siècle Dernier. Paris: J.-C. Lattès, c1993.

Sobieszek, Robert A. Masterpieces of Photography: From the George Eastman House Collections. New York: Abbeville Press, 1985.

Talbot, William Henry Fox. The Pencil of Nature. London: Longman Brown, Green \& Longmans, 1844-46.

Vaczek, Louis Charles. Travelers in Ancient Lands: A Portrait of the Middle East, 18391919. Boston: New York Graphic Society, 1981.

Valverde, María Fernanda. Photographic Negatives: Nature and Evolution of Process. Rochester, N Y: George Eastman House, 2005.

Xanthakis, Alkis. “Zangaki Brothers.” Fotografos, September 2005, 62.

— “Zangaki Brothers.” Optikon, December 1995.

- "Photographers, Greek and others, who photographed in Greece during the 19th and 20th-centuries." Working paper, Hellenic Historical 
Archive, Athens, 2008.

Zannier, Italo. L' Egitto del Grand Tour nella Fotografia degli Zangaki. Milano: CRAF, 1999.

\section{Reference and General History}

American Heritage Dictionary of the English Language. William Morris, editor. New York: Houghton Mifflin, 1973.

Costello, Bonnie, ed. The Selected Letters of Marianne Moore. New York: Knopf, 1997.

Egypt: Handbook for Travelers. ed. K. Baedeker. Leipsic, K. Baedeker; London, Dulau and Co., 1878-92.

Egypt: Handbook for Travelers. 4th remodelled ed. Leipsic, K. Baedeker; London, Dulau and Co., 1898.

Larousse, Pierre, ed. Grand Dictionnaire Universel du XIXe Siècle, XIV, Paris, 18661879, Biography of Mohammed Said.

Lawrence, T.E. and C. Leonard Woolley. Wilderness of Zin. London: Palestine Exploration Fund, 1915.

Miclewright, Nancy. A Victorian traveler in the Middle East: the Photography and Travel Writing of Annie Lady Brassey. Aldershot, England; Burlington, VT: Ashgate, c2003.

Murray, John. A Handbook for Travellers in Egypt. 4th ed., rev. on the spot. London: J. Murray, 1873.

Palestine and Syria. Handbook for Travellers. Ed. by K. Baedeker. Leipsic, K. Baedeker, 1876.

Palestine and Syria; Handbookfor Travellers, ed. by K. Baedeker. 2d ed., rev. and augm. Leipsic, K. Baedeker, 1894.

Peck, William Farley. History of Rochester and Monroe County. New York: The Pioneer publishing company, 1908.

Registrar records. 1978:1297-1315, November 7, 1978, George Eastman House.

Remington, Carolyn Lyon. Vibrant Silence; a Biography. Rochester, N.Y., Lawyers Cooperative Pub. Co., 1965. 
Renfrew, Colin and Malcolm Wagstaff, eds. An Island Polity: The Archaeology of Exploitation in Melos. Cambridge: Cambridge University Press, 1982.

Said, Edward W. Orientalism. New York: Pantheon Books, 1978.

Sontag, Susan. On Photography. New York: Farrar, Straus and Giroux, 1977.

Stauffer, Elizabeth M. "Edmund and Carolyn Lyons." George Eastman House collection records, 2003.

The World Book Encyclopedia, Volume 3. Field Enterprises Educational Corporation, 1960. 


\section{APPENDIX A}

\begin{tabular}{|c|c|c|}
\hline $\begin{array}{l}\text { Negative } \\
\text { Number }\end{array}$ & Object Number & Title on Print or Descriptive Title \\
\hline 1161 & 1973:0230:0001 & Jaffa, Vue d'Ensemble \\
\hline 1157 & 1973:0230:0002 & Bazar de Jaffa \\
\hline 1032 & 1973:0230:0003 & Panorama de Jerusalem \\
\hline illeg. & 1973:0230:0004 & Jerusalem, prix de l'Hotel Hovarts \\
\hline 1093 & 1973:0230:0008 & (Jerusalem) Prison de Jesus Christ \\
\hline 1095 & 1973:0230:0009 & (Jerusalem) Interieur de la Sainte-Croix \\
\hline 1040 & 1973:0230:0012 & (Jerusalem) Porte de Saint-Etienne \\
\hline illeg. & 1973:0230:0013 & Jerusalem, Via Dolorosa and House of Divas \\
\hline illeg. & 1973:0230:0014 & Jerusalem, The tomb of the Virgin \\
\hline illeg. & 1973:0230:0015 & $\begin{array}{l}\text { Jerusalem, From the Mount of Olives (Panorama de } \\
\text { Jerusalem No. 3) }\end{array}$ \\
\hline 1215 & 1973:0230:0016 & $\begin{array}{l}\text { (Mosquee d'Omar interieur (le rocher) Jerusalem, Interior of } \\
\text { mosque of Omar, "The Rock of Abraham." }\end{array}$ \\
\hline 1058 & 1973:0230:0017 & $\begin{array}{l}\text { Jerusalem, The Mosque of Omar (Mosquee d'Omar et } \\
\text { Tribunal de [illeg.]) }\end{array}$ \\
\hline illeg. & 1973:0230:0019 & Jerusalem-Mosque of Omar - "The Stables of Soloman." \\
\hline 1069 & 1973:0230:0021 & (Jerusalem) Mosquee El-Aksa vue generale \\
\hline 1066 & 1973:0230:0023 & $\begin{array}{l}\text { (Jerusalem) Maison de Pilate Temple enclosure, The House } \\
\text { of Pilate }\end{array}$ \\
\hline 1038 & 1973:0230:0024 & (Jerusalem) Porte de Damas The Damascus State \\
\hline 1022 & 1973:0230:0025 & Jerusalem, "The Grotto of Jeremiah" \\
\hline 1011 & 1973:0230:0026 & $\begin{array}{l}\text { Jerusalem, Valley of Jehoshaphat, Tombs of St. James and } \\
\text { Prophet Zacharias }\end{array}$ \\
\hline 1146 & 1973:0230:0027 & (Jerusalem) - "The Tombs of the Kings." Tombeau des Rois \\
\hline 1132 & 1973:0230:0029 & Road to Bethlehem from Jerusalem \\
\hline 1117 & 1973:0230:0033 & (Bethleem) Interieur de la Grotte de la Nativitie \\
\hline 1121 & 1973:0230:0034 & Environs of Bethlehem, "The Pool of Soloman" \\
\hline 1101 & 1973:0230:0035 & Tombeaux de Rachel pris Bethlehem \\
\hline 1012 & 1973:0230:0036 & (Jerusalem) Village de Siloam \\
\hline 1149 & 1973:0230:0037 & On the road to Jaffa, the Village of Emmans \\
\hline 1153 & 1973:0230:0038 & On the Road to Jaffa, The town of Ramleh \\
\hline 1130 & 1973:0230:0039 & On the Edge of the Jordan \\
\hline 1128 & 1973:0230:0040 & Le bain a la Mer Morte: The Shore of the Dead Sea \\
\hline no number & 1978:1297:0015 & Philae Vue prise de l'ile Bique \\
\hline
\end{tabular}

1978:1297:0016

\section{Location}

Provenance

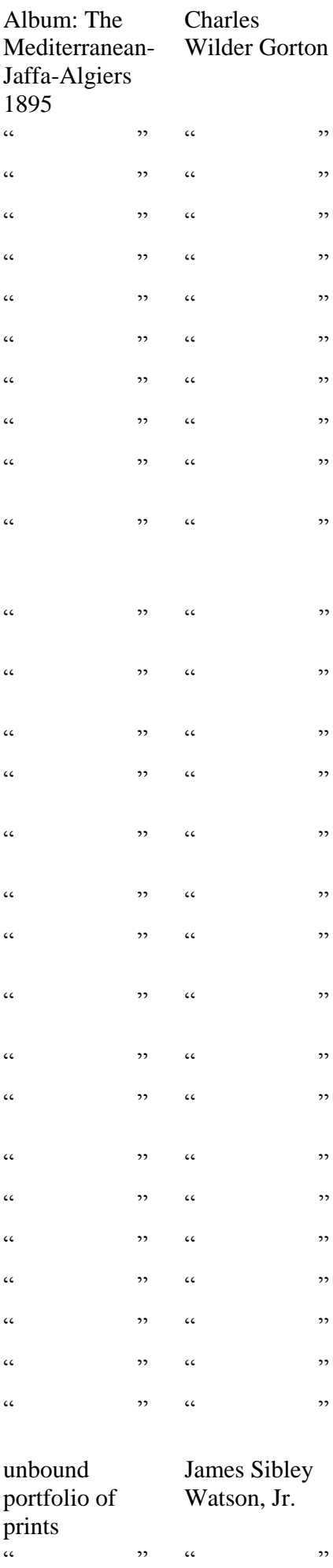


1978:1297:0017

1978:1297:0018

1978:1297:0019

1978:1297:0020

1978:1297:0021

1978:1297:0022

1978:1297:0023

1978:1297:0024

1978:1297:0025

1978:1297:0026

1978:1297:0027

1978:1297:0028

1978:1297:0029

1978:1297:0030

1978:1297:0031

1981:2125:0001

1981:2125:0002

1981:2125:0003

1981:2125:0004

1981:2125:0005

1981:2125:0006

1981:2125:0007

1981:2125:0008

1981:2125:0009

1981:2125:0010

1981:2125:0011

1981:2125:0012

1981:2125:0013

1981:2125:0014

1981:2126:0001

1981:2126:0002

1981:2126:0003

1981:2126:0004

1981:2126:0005

1981:2126:0006

1981:2126:0007

1983:1317:0001

1983:1317:0002

1983:1317:0003

1983:1345:0001
Phylae Temple d'Isis Interieur du premier pylons

Louqsor Le pylone les statues de Ramses

Thebes Ramsseon Vue panoramique avec tombeaux des Rois

Statue de Ramses a Louqsor

Thebes colosses de Memnon

Palmieres sur les bords du Nil

Marchand des tapis

Edfou Pylone du temple de Horus

Edfu Le [illegible]

Assouan Cataracte segonde porte

[illegible] Egyptian columns

Nubee Bicharins

Epicurie Arab

Karnak Salle hypostyle interieur

Jardin de l'Egypte

Dahabie montant le Nil

Les boeufs dans le Nil

Mosquee Saida - Zeynab Caire

Mosquee de Mohamet Ali Caire

Exportation dans le Nil

Passage au Pont de Kasr el Nil

Inondation au Pyramides

Bord du Nil a Boulaq

(Caire) Interieur de la Mosquee Hambro

Workers drawing water from the Nile: Not sure if Zangaki

Boat on the Nile: Not sure if Zangaki

Panorama du Vieux Caire et Pyramides

Panorama du Caire pris de la citadelle

Partie del Caire el Mosquee Hassan

La Mosquee Sultan Bebars Caire

Arivee du M[illeg.ible]el Caire

Mosquee El- Husseni Caire

(Caire) Ville Arab

Tombeaux des Mamelouks Caire

men smoking hookah at a café: no title, not sure if Zangaki

Mosquee de Mohamet Ali

Caire Vue Panoramique

Palmiers [illegible]

Femmes arabes sur Baudets

Bord du Nil et Palmiers

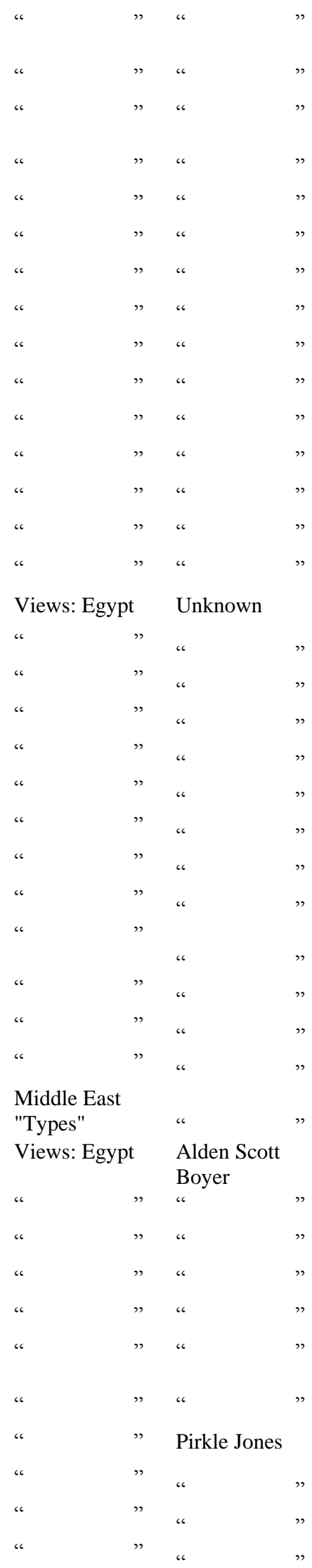

Hackman 59 


\begin{tabular}{|c|c|c|}
\hline 630 & 2000:0817:0002 & Chadoufs de la Haute Egypte \\
\hline 540 & 2000:0814:0015 & Laggeh Egyptiene \\
\hline 725 & 1986:0309:0084 & Abydos Tableau des 76 Rois d' Egypte \\
\hline 360 & 1986:0309:0086 & Palmiers sur les bords du Nil \\
\hline no number & 1986:0309:0089 & Pont du Kasr-el-nil-caire \\
\hline 643 & 1986:0309:0102 & Statue de Memphis a Sakkara \\
\hline 702 & 1986:0310:0001 & Karnak Temple le Khons Interieur \\
\hline 30 & 1986:0310:0002 & Print is light and faded too much at bottom to read title \\
\hline 461 & 1986:0310:0003 & Drague a longue couloire \\
\hline 456 & 1986:0310:0005 & Rue du comerce a Port-Said \\
\hline 662 & 1988:0355:0001 & Dinar arabe \\
\hline 673 & 1988:0355:0002 & Marchand d'eau \\
\hline 919 & 1988:0355:0003 & Ensemble du Ramseum Thebes \\
\hline 969 & 1988:0355:0004 & Statue de Ramses a Lougsor \\
\hline 1015 & 1988:0355:0005 & Karnak Grande porte de [illeg..]olomee \\
\hline 578 & 1988:0355:0006 & [illeg..] de mariage arabe \\
\hline no number & 1988:0355:0007 & Femme Turque Voilee \\
\hline no number & 2001:1522:0001 & Quai du Port-Said \\
\hline 669 & 2001:1522:0002 & Loucsor Jardin de Loucsor Hotel \\
\hline 753 & 2001:1522:0003 & Ile. de rocher Konosso \\
\hline 674 & 2001:1522:0004 & $\begin{array}{l}\text { Louqsor propylone du temple de...et les statues } \\
\text { de... [ellipses in negative] }\end{array}$ \\
\hline 152 & 2001:1522:0005 & Bain des...[illegible text] \\
\hline 711 & 2001:1522:0006 & Colonade a Louqsar \\
\hline 458 & 2001:1522:0007 & Rue du comerce a Port-Said \\
\hline 646 & 2001:1522:0008 & Assiout \\
\hline 763 & 2001:1522:0009 & Assouan Tombeau d' Amenhotep 1466 a. J.C. \\
\hline 765 & 2001:1522:0010 & Assouan vue panoramique \\
\hline 642 & 2001:1522:0011 & Haute Eqypte Bateau postale \\
\hline 196 & 2001:1522:0012 & Promenade de [illegible] Caire \\
\hline 767 & 2001:1522:0013 & Assouan Bains de Cleopatra et ile Elephantine \\
\hline 647 & 2001:1522:0014 & Panoram [edge of print trimmed here] \\
\hline 206 & 2001:1522:0015 & Le Sphynx Caire \\
\hline 376 & 2001:1522:0016 & Vue des trois Pyramides \\
\hline
\end{tabular}
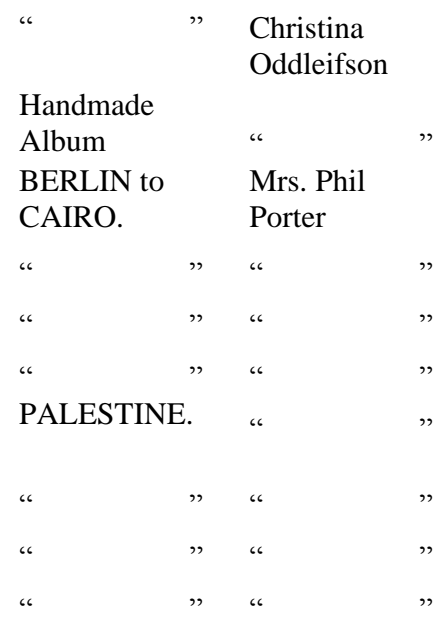

Lantern Slides Edward Lennert

\begin{tabular}{|c|c|c|}
\hline ، & $"$ & " \\
\hline “ & $"$ & “ \\
\hline “ & $"$ & " \\
\hline “ & $"$ & “ \\
\hline “ & 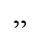 & “ \\
\hline “ & " & “ \\
\hline & & Eugene Van \\
\hline & & Voorhis \\
\hline
\end{tabular}

\begin{tabular}{|c|c|c|}
\hline “" & " & “" \\
\hline "“ & $"$ & " \\
\hline “" & $"$ & “ \\
\hline " & , & ، \\
\hline " & $"$ & ، \\
\hline "“ & , & ، \\
\hline " & $"$ & “" \\
\hline “ & , & ، \\
\hline " & $"$ & ، \\
\hline " & , & ، \\
\hline " & $"$ & ، \\
\hline " & $"$ & ، \\
\hline "“ & 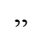 & “" \\
\hline "، & , & ، \\
\hline ، & , & ، \\
\hline
\end{tabular}




\title{
APPENDIX B
}

\author{
Negative Number Title on Print or Descriptive Title \\ 3 Courbe d'El guirs \\ 4 Seuil d' El guirs \\ 10 Kantara \\ 14 Drague 'Derocheuse' \\ 14 Chalet de Vice Roi \\ 18 Port-Said rue de la Poste \\ 22 Rue du Comerce [sic] a Port-Said (same as porter album, \\ different number; print is blurry!? Did they wash off the \# \\ and re-paint it?) \\ Place de Lesseps a Port-Said \\ Port-Said Village arabe \\ Pont des caravannes de la Syrie Kantara \\ Print is light and faded too much at bottom to read title \\ Gare de Deversour \\ Eclouse aval a Ismailia \\ Croisement de l'Orient Toussoum \\ Une rue de Suez \\ Groupe des dattiees a Fontane de Moise \\ General view of the pyramids
}

118

118

125

146

152
Hunters and their bounty after a crocodile hunt on the Nile Embouchure du Canal a lac Timsah

Suez Maree basse

Port Tewfik a Suez

Bain des...(illegible text)

Partie del Caire el Mosquee Hassan

Suez Maree basse

Dahabieh et pont de Kasr-el-Nil

Sphinx

\section{Le Sphinx (with darkroom wagon on left)}

\section{Pont des caravannes de la meque}

Sphynx et le Grande Pyramide Cheops

Sphynx et le Grande Pyramide Cheops

Bord du Nil

Bord du Nile (Scenes de la vie quotidienne)

Palais de Gezirah

Mosquee de Mohamet Ali Caire

Mosquee de Mohamet Ali Caire

Vue generale d' Alexandrie prise du Phare

Port d'Alexandria

Panorama du Caire pris de la citadelle

Promenade de [Illegible] Caire

Le Muezz[...] Caire

Mosquee de Mohamet Ali

\section{Institution}

New York Public Library (NYPL)

NYPL

NYPL

Harvard Fine Arts Library (FAL)

NYPL

Harvard FAL

Harvard FAL

Harvard FAL

Harvard FAL

Harvard FAL

George Eastman House (GEH)

NYPL

Harvard FAL

NYPL

Harvard FAL

NYPL

An den süssen Ufern Asiens: (On the Sweet Banks of Asia: Egypt, Palestine, the Ottoman Empire: Travel destinations of the 19th century in early photographs.)

An den süssen Ufern Asiens.

Harvard FAL

Harvard FAL

Harvard FAL

GEH

GEH

Harvard FAL

NYPL

Jacobson, Ken. Odalisques \& arabesques:

Orientalist photography 1839- 1925. London:

Quaritch, 2007.

Simoën, Jean-Claude. L'Egypte éternelle: les voyageurs photographes au siècle dernier. Paris: J.-C. Lattès, c1993.

NYPL

NYPL

NYPL

Miclewright, Nancy. A Victorian traveler in the Middle East: the photography and travel writing of Annie Lady Brassey. Aldershot, England; Burlington, VT: Ashgate, c2003.

Simoën, Jean-Claude. L'Egypte éternelle.

Harvard FAL

GEH

Harvard FAL

NYPL

NYPL

GEH

GEH

Harvard FAL

GEH 
210 Alexandrie Colone

acombes d'Alexandria

Untitled (Alexandria, Midan Tahrir [originally Place des Consuls; at that time Place Muhammad Ali], general view looking NW from on top of the rubble down its length after the infamous British Naval bombardment of July 11, 1882.

233 Palmiers [Illegible]

235 Vue generale de la citadelle

237 Vue de Caire et mosque Sultan Hassan

239 Caire Vue Panoramique

240 Caire vue d'ensemble

252 Marchand des tapis

253 Changeur egyptien

262 Jardin de l'Egypte

263 Chech Arab (Sheik)

263 Chech Arab

295 Caire, Panorama de la Citadelle [Cairo, view of the eastern side of the Citadel taken from the Maqattam Hills]

296 Panorama de vieux Caire et Pyramides [Panorama of Cairo and the Pyramids taken from the Citadel]
Interieur de l'eglise Cophte Caire

Grand bazar au Kasr-el-Nil Caire

Mosquee Saida Zeynab Caire

Vue generalle de Pyramides

Palmiers sur les bords du Nil

(Caire) Ville Arab

Bord du Nil et Palmiers

Avenur des Pyramides

Vue des trois Pyramides

Vue generale des pyramides

Palmieres sur les bords du Nil

Grand Bazar au Kasr el Nile Caire

Caire New Hotel

Caire New Hotel

(Caire) Interieur de la Mosquee Hambro

(Caire) Interieur de la Mosquee $\mathrm{Ha}[\ldots]$

Statue de Memphis a [illeg]

Caire Obelisque d' Heliopolis

Obelisque d'Heliopolis

L'Arabe de la vierge

passage au pont de kasr el nil

Ascending pyramid

Inondation du Nil [cut off]

Sphynx decouvert

Abyssinian Soldier at Dogal

Sphynx arruaches
Porte de la Mosquee Hasan

Pyramide de Cheops le sphinx et le temple de Chefren
GEH

NYPL

NYPL

Harvard FAL

GEH

NYPL

NYPL

GEH

Harvard FAL

GEH

Harvard FAL

GEH

Simoën, Jean-Claude. L'Egypte éternelle.

NYPL

Chevedden, Paul. "The Photographic Heritage of the Middle East: an exhibition of early photographs of Egypt, Palestine, Syria, Turkey, Greece \& Iran, 1849-1893". Malibu, Calif:

Undena Publications, c1981.

Chevedden, Paul. "The Photographic Heritage of the Middle East"

Harvard FAL

Harvard FAL

NYPL

Harvard FAL

Simoën, Jean-Claude. L'Egypte éternelle.

GEH

GEH

GEH

Harvard FAL

GEH

NYPL

GEH

LoC

NYPL

NYPL

NYPL

GEH

Harvard FAL

NYPL

Harvard FAL

NYPL

NYPL

NYPL

D'Hooghe, Alain and Marie-Cecile Bruwier. The Great Pyramids of Giza. Paris, ViloPublilshers, 2000.

NYPL

D'Hooghe, Alain The Great Pyramids of Giza.

Vaczek, Louis Charles. Travelers in Ancient

Lands: A Portrait of the Middle East, 1839-1919.

Boston: New York Graphic Society, 1981.

D'Hooghe, Alain The Great Pyramids of Giza. 
$\begin{array}{ll}456 & \text { Rue du comerce a Port-Said } \\ 457 & \text { Pyramide de S(P)akkara } \\ 457 & \text { (Man in studio posing with huge calf-skin water bottle; } \\ & \text { studio head-stand visible in background) } \\ 458 & \text { Rue du comerce a Port-Said } \\ 461 & \text { Drague a longue couloire } \\ 472 & \text { Chamaux de mariage arabe } \\ 472 & \text { [illeg] de marriage arabe } \\ 480 & \text { Palais de Ras el tin a Alexandria } \\ 486 & \text { Sakkieh dans la Haute Egypte } \\ 493 & \text { Palmieres vis a vis du Kasr -el-Nil } \\ 521 & \text { Soldat Alyssin a Degate } \\ 540 & \text { Laggeh Egyptiene (Guy at well with cow turning weheel) } \\ & \\ 545 & \text { Ecole arabe } \\ 548 & \text { Almee arabe [cut off] } \\ 555 & \text { Le someille profond } \\ 559 & \text { Visit [illeg] (man next to donkey pulling cart with } 5 \\ & \text { women) } \\ 562 & \text { Invitation d'un mariage arab } \\ 564 & \text { Porteurs d'eau sur les bords du Nil } \\ & \\ 565 & \text { Voiture arab } \\ 576 & \text { Femmes arabes sur Baudets } \\ 581 & \text { Cpicurie Arab } \\ 582 & \text { Charmeur des Serpen[cut off] } \\ 578 & \text { Repos d'un chameau } \\ & \\ 5 & \end{array}$

598 Diner arab

602 Group of Bedouins
GEH

AGO

Harvard FAL

GEH

GEH

Harvard FAL

NYPL

Harvard FAL

NYPL

AGO

AGO

GEH

NYPL

NYPL

NYPL

NYPL

NYPL

Simoën, Jean-Claude. L'Egypte éternelle.

Simoën, Jean-Claude. L'Egypte éternelle.

GEH

GEH

NYPL

GEH

NYPL

Aubenas, Sylvie and Jacques Lacarrière. Voyage en Orient. Paris: Hazan: Bibliothèque Nationale de France, 1999.

Harvard FAL

Jacobson, Ken. Odalisques \& Arabesques: Orientalist Photography 1839- 1925. London: Quaritch, 2007.

NYPL

Harvard FAL

GEH

Aubenas, Voyage en Orient.

AGO

Harvard FAL

Perez

GEH

GEH

GEH

LoC 
Assiout

Station Hotel at Assiut

647

660 Thebes colosses de Memnon
661 Thebes Ramsseon Vue panoramique avec tombeaux des Rois

662 Dinar arabe.

664 Epicure Arabe

669 Loucsor Jardin de Loucsor Hotel

671 Louqsor Le pylone les statues de Ramses

673 Marchand d'eau.

674 Louqsor propylone du temple de...et les statues de... [both times the ellipses are in the negative].

678

682 Karnak Grand Temple

685 Karnak Ruines obelisque de Touthmes 1 et de sa fille Hatasou

686 Karnak - Tableau de Victoire sur [...]

688 Karnak Interieur du temple de K

689 Karnak Ruinee

695 Karnak Salle hypostyle interieur

698 View of temple with obelisques of Thothmes + his daughter Hatasu (sic)

702 Karnak Temple le Khons Interieur

708 Karnak...Touthmes...

709 Karnak porte du grand temple de Khons avec l'avenue de B[illeg]

711 Colonade a Louqsar

718 E...[illeg] Colonade souterraine

723 Offrande Doli

725 Abydos Tableau des 76 Rois d' Egypte

729 Pylon du temple d'Athor a Denderak

740 Phylae Temple d'Isis Interieur du premier pylons

750 Portrait of Two Arab Women
GEH
GEH
NYPL
GEH
NYPL
GEH
GEH
AGO
NYPL
NYPL
GEH

GEH

Bull, Deborah. Up the Nile: A photographic excursion, egypt 1839-1898. New York: C. N. Potter, 1979.

GEH

NYPL

Harvard FAL

Harvard FAL

GEH

GEH

GEH

LoC

GEH

GEH

GEH

GEH

NYPL

NYPL

NYPL

Harvard FAL

GEH

NYPL

GEH

Harvard FAL

GEH

Harvard FAL

NYPL

GEH

NYPL

NYPL

GEH

NYPL

GEH

Bull, Deborah, Up the Nile. 
Ile. de rocher Konosso

A View of the Train Station at Aswan

No Z signature (Greek Bishop)

Vue generalle de Louqsor

Caire Maison arabe et Mouchrabieh

Caire Interieur de la mosquee el Kallarvoom

Assouan Tombeau d' Amenhotep 1466 a. J.C.

Assouan vue panoramique

Assouan Cataracte segonde porte

Edfou Façade du temple

Assouan Bains de Cleopatra et ile Elephantine

Chadoufs a $[\ldots]$

Laggieh Egypte

Tombeaux des Mamelouks Caire

Moulet-el-Neby Fete arabe

Passage au Pont de Kasr el Nil

Abydos off[illeg]

Inondation au Pyramides (I did not cataloge)

Pyramide et Cheops

Bas relief du temple Edfou (Horus and Isis)

Kom-Ombo temple de Sebek et Horus

Laggieh

Bord du Nil a Boulaq (Cairo)

Inondation du nil et palmiers

Palmiers et Pyramides

Vue generale de Philae

Phylae cote Nrod

Groupe des Minarets Mosquee El-A [...]

Phylae panorama du Nord

Mosquee Saida - Zeynab Caire

Groupe de femmes de harem

Mosquee El- Husseni Caire

Arivee du M[illegible]el Caire

La Mosquee Sultan Bebars Caire

Panorama du Vieux Caire et Pyramides

Abydos Interieur

Ferme d' Autruches (ostriches)

Abydos Ramses II

Denderah temple

Denderah Entrée d antinaos

Denderah Colonnade

Femmes arabes sur Baudets

Temple Athor Denderah

Ensemble du Ramseum Thebes.

Statue de Ramses III Thebes

Thebes Interieur de tombe de roi N.6

Thebes tombe de roi

Vue generalle de Louxor

Statues decorati...[illeg] a Louqsor

Luksor Colonnade du temple

Statue de Ramses a Karnak

Statue de Ramses a Louxsor.
GEH

Bull, Deborah, Up the Nile.

Harvard FAL

NYPL

Harvard FAL

Harvard FAL

GEH

GEH

GEH

Simoën, Jean-Claude. L'Egypte éternelle.

GEH

Harvard FAL

NYPL

GEH

NYPL

GEH

NYPL

GEH

NYPL

Harvard FAL

Harvard FAL

NYPL

GEH

NYPL

Simoën, Jean-Claude. L'Egypte éternelle.

Harvard FAL

NYPL

Harvard FAL

NYPL

GEH

Aubenas, Voyage en Orient.

GEH

GEH

GEH

GEH

AGO

Harvard FAL

AGO

AGO

AGO

Harvard FAL

NYPL

Harvard FAL

GEH

AGO

AGO

AGO

AGO

NYPL

Harvard FAL

NYPL

GEH 
975 Louxor ensemble des colonnades

980 Turkish Dancers

997 Ruins at Karnak

1003 Karmak Ruine obelisque de Touthmes 1st et de sa fille Katasese

1005 Garden of Gethsemane in Jerusalem.

1005 Garden of Gethsemane c. 1880

1009 Karnak Grand tenle avec Obelisque de Touthmes

1011 Jerusalem, Valley of Jehoshaphat, Tombs of St. James and Prophet Zacharias

1011 Karnak colonnade de la salle hypostyle

1012 (Jerusalem) Village de Siloam

1015 Karnak Grande porte de (illeg.)olomee.

1022 Jerusalem, "The Grotto of Jeremiah"

1024 Edfou Interieur du temple

1025 Edfou Vue generale du temple

1025 Edfou Vue generale du temple

1026 Edfou Pylon du temple de Horus

1032 Panorama de Jerusalem

1032 Edfou Interieur

1037 Edfou Bas-relief du temple de Horus

1038

(Jerusalem) Porte de Damas The Damascus State

1039 Jaffa Gate in Jerusalem

1040 (Jerusalem) Porte de Saint-Etienne

1043 Edfou Bas-relief du temple de Horous

1044 Edfou Interieur, Barque [...]

1056 Assouan premier caracte

1058 Jerusalem, The Mosque of Omar (Mosquee d'Omar et Tribunal de [illeg])

1059 Nile, Cataracte, Seconde (from HSM card catalog)

1063 Entrance to the cave in the Dome of the Rock in Jerusalem.
Jacobson, Ken. Odalisques \& Arabesques: Orientalist Photography.

AGO

Vaczek, Louis Charles. Travelers in Ancient

Lands.

Harvard FAL

AGO

Palestinian Exploration Fund (PEF)

Osman, Colin. Jerusalem: caught in time. New York: New York University Press, 2000.

AGO

GEH

Harvard FAL

GEH

GEH

GEH

AGO

AGO

Harvard FAL

Harvard FAL

GEH

AGO

AGO

GEH

PEF

GEH

AGO

Harvard FAL

AGO

GEH

Harvard FAL

PEF

GEH

GEH

Harvard FAL

AGO

AGO 
1093 (Jerusalem) Prison de Jesus Christ GEH

1095 (Jerusalem) Interieur de la Sainte-Croix (Not in TMS as Z) GEH

1101 Tombeaux de Rachel pris Bethlehem (NOT in TMS as Z) GEH

1109 Railway to Jerusalem PEF

1110 Bridge of the railway line from Jaffa to Jerusalem. PEF

1111 View of Bethlehem. PEF

1113 Tower at Ramleh PEF

1117 (Bethleem) Interieur de la Grotte de la Nativitie GEH

1121 Environs of Bethlehem, "The Pool of Soloman" GEH

1125 Vue generale de Jerusalem Harvard FAL

1128 Le bain a la Mer Morte: The Shore of the Dead Sea GEH

1128 View of the Old City of Jerusalem PEF

1129 General view of the Old City of Jerusalem from the Mount PEF of Olives towards the W.

1129 General view of the Old City of Jerusalem from the Mount of Olives towards the W.

1129 Where the Jordan meets the Dead Sea

Images of the Orient: photography and tourism, 1860-1900. Eds. Paul Faber, Anneke Groeneveld, Hein Reedijk. Amsterdam: Fragment in samenwerking met Museum voor Volkenkunde, Rotterdam, c1986.

1130 On the Edge of the Jordan GEH

1132 Road to Bethlehem from Jerusalem (NOT in TMS as Z) GEH

1136 View of Jerusalem with the Church of St Anne and the PEF Dome of the Rock in the background.

1137 General view of the northern city wall of Jerusalem and the PEF Damascus Gate (centre) with the Holy Sepulchre in the background.

1137 General view of the northern city wall of Jerusalem and the Damascus Gate (centre) with the Holy Sepulchre in the background.

1143 Jaffa Street leading to the Old City of Jerusalem.

PEF 
1144 View of the Jaffa Gate from inside the walls looking west. PEF

1144 The Jaffa Gate c. 1900

1146 (Jerusalem) - "The Tombs of the Kings." Tombeau des Rois

1149 On the road to Jaffa, the Village of Emmans (NOT in TMS as Z)

1149 Jaffa Gate, Jerusalem.

1153 On the Road to Jaffa, The town of Ramleh

1154 El Wad Street, Vaulted street in the old city of Jerusalem

1157 Bazar de Jaffa

1158 Jaffa, House of Simon the Tanner

1161 Jaffa, Vue d'Ensemble

1163 The Via Dolorosa in Jerusalem.

1175 The interior of the Edicule in the Church of the Holy Sepulchre.

1175 The Chapel of the Angel c. 1885

1177 Dome of the Church of the Holy Sepulchre, Jerusalem.

1177 View of the Dome of the Church of the Holy Sepulchre in Jerusalem.

1184 The Edicule in the Church of the Holy Sepulchre.

1185 The Edicule of the Church of the Holy Sepulchre, Jerusalem.

1187 Jerusalem Cathedrale Greque dans la basilique

1191 A detail of one of the entrances to the Dome of the Rock in Jerusalem

1192 Mosquee d'Omar

1194 (Jerusalem) Mosquee d'Omar et Tribunal de David

1195 The Dome of the Chain or Mahkamat Da'ud (David's Tribunal) east of the Dome of the Rock in Jerusalem.
Osman, Colin. Jerusalem: Caught in Time.

GEH

GEH

PEF

1973:0230:0038

$\mathrm{PEF}$

PEF

Onne, Eyal. Photographic Heritage of the Holy Land, 1839-1914. Manchester, England: Institute of Advanced Studies, Manchester Polytechnic, 1980.

GEH

PEF

PEF

Osman, Colin. Jerusalem: Caught in Time.

PEF

PEF

PEF

PEF

Harvard FAL

PEF

Harvard FAL

Harvard FAL

PEF

PEF 
1199

(Jerusalem) Mosquee d'Omar interieur le rocher

1201 Interior of the Church of St Anne in Jerusalem.

1201 Interior of the Church of St. Anne. C. 1885

1213 Interior of the Mosque El Aqsa, Jerusalem.

1213 Interior of the Mosque of El Aqsa, Jerusalem.

1213 Interior of El Aksa Mosque C. 1885

1213 (Jerusalem) Mosquee El-Aksa interieur

1215 (Mosquee d'Omar interieur (le rocher)) Jerusalem, Interior of mosque of Omar, "The Rock of Abraham."

1219 The northern end of the Haram al-Sharif, looking NW.

1230 View of the so-called Hezekiah's Pool, in Jerusalem.

1230 The Pool of Hezekiah looking NE, Jerusalem

1236 Interior of the Chapel of St Helena in the Church of the Holy Sepulchre in Jerusalem.

1236 The Fifteenth Station of the Cross: the Chapel of Saint Helena c. 1885

1238 The Ecce Homo Arch (in the distance) in Jerusalem

1241 View of the building associated with the Tomb of David on Mount Zion, Jerusalem.

1257 The road to Bethlehem outside the Jaffa Gate in Jerusalem.

1257 The Road to Bethlehem. C. 1890

1260 A general view of the Tomb of Rachel, Bethlehem

1264 General view of Bethlehem.

1268 General view of Bethlehem

1269 View of Bethlehem

1269 Bethleem Panorama

1270 Church of the Nativity in Bethlehem

1273 Interior of the cave in the Church of the Nativity, Bethlehem

1282 The monastery of Mar Saba
Harvard FAL

PEF

Osman, Colin. Jerusalem: Caught in Time.

PEF

PEF

Osman, Colin. Jerusalem: Caught in Time.

Harvard FAL

GEH

PEF

PEF

PEF

PEF

Osman, Colin. Jerusalem: Caught in Time.

PEF

PEF

PEF

Osman, Colin. Jerusalem: Caught in Time.

PEF

PEF

PEF

PEF

Harvard FAL

PEF

PEF

PEF 
1287 Bethlehem, pools of Solomon, General View

1288 Interior of the Church of the Virgin's Tomb.

1292 Olive tree in the Garden of Gethsemane, Jerusalem

1297 The Church of the Paternoster on the Mount of Olives, Jerusalem

1297 Church of the Pater Noster c. 1885

1299 Interior of the Chapel of the Ascension.

1307 (Jerusalem) Tombs in the Valley of the Kidron (from HSM card catalog)

1308 Bethleem Panorama

1334 The Dead Sea, (Voyage dan la mer Morte)

1356 Ruins on the summit of Mount Tabor.

1373 Ayn al-Mraysseh, vue prise de la pointe de Ras-Beyrouth
Harvard FAL

PEF

PEF

PEF

Osman, Colin. Jerusalem: Caught in Time.

PEF

Harvard FAL

Harvard FAL

Onne, Eyal. Photographic Heritage of the Holy Land.

PEF

Debbas, Fouad. Des photographes à Beyrouth, 1840-1918. Paris: Marval, 2001. 